\title{
Political Martyrdom and Religious Censorship in Islamic Sicily: a Case Study During the Age of Ibrāhīm II (261-289/875-902)*
}

\author{
Martirio político y censura religiosa en \\ la Sicilia islámica: un caso de la época \\ de Ibrāhīm II (261-289/875-902)
}

\author{
Giuseppe Mandalà \\ ILC-CCHS, CSIC, Madrid
}

\begin{abstract}
At the end of Sicily's Islamic period, the Mālikī juridical school was firmly rooted and documented in the island; but like many aspects of the cultural life of the island during the Islamic Age, the historical process that led to this situation is yet to be clarified. The present study aims to contribute by providing a historical context for a passage of the Kitāb al-mihan, a book of Islamic martyrology written by Abū l-'Arab Muhammad al-Tamīmī (d. $333 / 945$ ), which until now has been overlooked by every study - both old and new on Islamic Sicily. The works relates how a judge living and working in Sicily, Ahmad b. Muḥammad al-Ṭā' '̀, known as Ibn al-Majjānī, was imprisoned and tortured at the behest of Ibrāhīm II (261-289/875-902), the Aghlabid sovereign who has been of most interest to historians. Other than establishing a plausible date for the event $(275 / 888-889)$, the article analyses the historical role of places and people, placing the 'martyrdom' of Ibn al-Majjānī in the context of the political repression exerted by Ibrāhīm II following the episode of
\end{abstract}

Al final del periodo islámico en Sicilia, la escuela jurídica mālikí estaba firmemente arraigada y documentada en la isla, pero, como ocurre con otros muchos aspectos de su vida cultural en época islámica, el proceso histórico que había llevado a esa situación todavía necesita ser aclarado. Este estudio tiene como objetivo proporcionar a suministrar un contexto histórico para entender un pasaje del Kitāb al-mihan, obra de martirología islámica compuesta por Abū 1-'Arab Muhammad al-Tamìmī (m. 333/945), pasaje al que hasta ahora no se ha prestado atención en los estudios antiguos y modernos sobre la Sicilia islámica. En él se relata cómo un juez que vivía y trabajaba en Sicilia, Ahmad b. Muhammad al-Ṭā' $\mathbf{1}$, conocido por Ib̉n al-Maŷŷānī, fue hecho prisionero y torturado por orden de Ibrāhīm II (261-289/875-902), el gobernante aglabí al que los historiadores han prestado una atención especial. Además de establecer una fecha plausible para este acontecimiento (275/888889), se analiza el papel histórico de lugares y personajes, situando el «martirio» de Ibn al-

* The first draft of this paper was presented at the panel "Knowledge under control. Political and religious censorship in Islamic societies," WOCMES, Barcelona, 19-24 July 2010, organized by the ARG-ERC project KOHEPOCU ("Knowledge, heresy and political culture in the Medieval Islamic West"). The research for this essay has been carried out within the project "Islam and religious in Early Modern Spain: between Reformation and Counter-Reformation Europe" (FF 12010-17745) directed by Mercedes Garcia-Arenal. 
Ibn TTālib (d. 275/888-889) and the subsequent religious censorship imposed by the Aghlabid at the expense of the Mālikī élites in Ifríqiya and, perhaps also, in the nearby wilaya of Sicily.

Key words: Mālikī juridical school; Islamic Sicily; Martyrology; Abū 1-'Arab Muhammad al-Tamīmī; Kitāb al-mihan; Ibrāhīm II; Ibn Tālib's affairs; Ahmad b. Muhammad al-Ṭā'̄ known as Ibn al-Majjānī; religious repression.
Maŷŷānī en el contexto de la represión política llevada a cabo por Ibrāhīm II tras el episodio de Ibn Tālib (m. 275/888-889) y la consiguiente censura religiosa impuesta por el emir aglabí sobre las elites mālikíes en Ifrīqiya y también, tal vez, en la cercana wilāya de Sicilia.

Palabras clave: escuela jurídica mālikí; Sicilia islámica; martirología; Abū 1-‘Arab Muhammad al-Tamīmī; Kitāb al-mihan; Ibrāhīm II; episodio de Ibn Ṭālib; Aḥmad b. Muhammad al-Ṭā'ì conocido por Ibn al-Maŷŷānī; represión religiosa.

For judges of Sicily, past and present

\section{The text}

I would here like to introduce a text - which has been overlooked by previous research on Islamic Sicily - that will provide an insight into the political and religious control exerted on the magistrature of the island during the Aghlabid period. The passage examined comes from a published source, the Kitāb al-mihan, a book of Islamic martyrology written by Abū 1-'Arab Muhammad b. Aḥmad b. Tamìm b. Tammām b. Tamīm al-Tamīmīi, a faqīh, traditionist, historian and poet from al-Qayrawān, and a member of a prestigious Arab family (his greatgrandfather was governor of Ifrīqiya and besieged al-Qayrawān in $183 / 799$, ending his days in prison in Baghdad). Abū 1-'Arab was born in al-Qayrawān between 250/864 and 260/873 and studied under eminent teachers, before taking on students himself, including the famous Ibn Abī Zayd al-Qayrawānī. Abū 1-'Arab took part in the insurrection of Abū Yazīd against the Fạtimids and died in prison in 333/945, because of his support for the Aghlabids and Sunnī Mālikīs. ${ }^{2}$

Amongst the works of fiqh, hadith and qad̄' ' attributed to him, the Tabaqāt 'ulamā' Ifriqiya is of particular interest for the history of Aghlabid Sicily, as it contains an important collection of biographies of North African Sunnī scholars, active between $4^{\text {th }}$ H. $/ 10^{\text {th }}$ A.D. $-6^{\text {th }}$

${ }^{1}$ Edition: Abū 1-'Arab, Kitāab al-mihan, pp. 7-37; on this work and its context see also Kister, "The Kitab al-Mihan, a Book on Muslim Martyrology;" Mansouri, "Les 'ulamā' en rupture avec le pouvoir en Ifrīqiya d'après le Kitāb al-mihan".

${ }^{2}$ Abū l-'Arab/al-Khushanī, Classes des savantes de l'Ifrìqiya, trans. Ben Cheneb, pp. V-XXVI; Rosenthal, "Abū 1-'Arab Muhammad b. Tamīm b. Tammām al-Tamīmī," p. 106; Mansouri, "Les 'ulamā' en rupture," pp. 567-568. 
H. $/ 12^{\text {th }}$ A.D. ${ }^{3}$ Another work, which has been preserved in a single manuscript held at Cambridge University Library (Qq. 235), is the Kitāb al-mihan, a text in the tradition of the maqātil, a collection of "illustrious murders," including imprisonments and corporal punishments; it begins with the execution of the caliph 'Umar ibn al-Khattāb and concludes at the time of its writing. ${ }^{4}$ The book mainly focuses on the 'ulama', or scholars of Islam, an "emotional community" that performed the role of intermediary between ruling powers and society. Often in disagreement or in open conflict with the power and its representatives, the 'ulama' ' that are considered in the book were subjected to violent and public trials and torture, ${ }^{5}$ a true and proper form of religious censorship that elevated them to political martyrdom, which they often wilfully and purposefully sought. ${ }^{6}$

The following passage clearly expresses the conflict between the 'ulam $\bar{a}$ ' and the ruling powers. It comes from the chapter that concerns "The Punishment Inflicted on the Judges of Ibn Țālib and his Provincial Magistrates (hukkāmu-hu fi l-buldān), "’7 from which we learn that:

Ibrāhīm ibn Ahmad dismissed Aḥmad b. Muhammad al-Ṭā'̄î, known as Ibn alMajjānī, from the office of $q \bar{a} d \underline{\imath}$ of Sicily. Previously Ibn Ṭālib appointed him judge of the island, but [Ibrāhīm] imprisoned him in Sicily and, at his command, Ibn alTiflī subjected him to torture.

${ }^{3}$ Edition: Ben Cheneb, "Additions à la 'Biblioteca arabo-sicula';" French translation Abū 1-'Arab, Classes des savantes; see also Fagnan, "Les tabakāt malekites".

${ }^{4}$ Abū 1-'Arab, Kitāb al-mihan, pp. 462-468.

5 This is the meaning of the word mihna, plural mihan; the author himself lists the different types of punishment: imprisonment, flogging, beating, humiliation and intimidation, see Abū l-'Arab Kitāb al-mihan, p. 287; Mansouri, "Les 'ulamā'en rupture," p. 571.

${ }^{6}$ See the accurate observations of Mansouri, "Les 'ulamā' en rupture," pp. 570-571, 575-577. On the definition of the idea of the "martyr" in Islam, see the overview by Cook, Martyrdom in Islam; for a more specific analysis on the casuistry considered in the Mālikî doctrine, see Penelas, "Introducción a la doctrina mālikí sobre el martirio". In contrast to another historiographic genre, the chronicles of al-Andalus, there seems to be a consistent desire to avoid executing rebels, so that they cannot then become martyrs in the eyes of their followers, see de la Puente, "En las cárceles del poder: prisión en al-Andalus bajo los omeyas (ss. II/VIII-IV/IX)," p. 107.

7 Abū l-Arab, Kitāb al-mihan, pp. 463-466. On the roles of the hăkim, "magistrati correzionali o ufiziali di polizia giudiziaria," see Amari, Storia dei Musulmani di Sicilia, II, p. 5; Dachraoui, Le califat fătimide au Maghreb (296-365 H./909-975 J. Ch.). Histoire politique et institutions, pp. 416-417; see also the definition given by Dozy: "l'officier chargé de surveiller l'administration judiciaire et de faire exécuter les sentences prononcées par les cadis; il indiquait aussi à ces derniers les personnes dont le témoignage pourrait être reçu au tribunal," Dozy, Supplément aux dictionnaire arabes, I, p. 310. 


\begin{abstract}
A Sicilian related that Ibn al-Ṭiflì had given the order to flog him with soaked papyrus rolls, and he [Ibn al-Majjānī] had already undergone a significant part of the punishment.

He [the Sicilian] said: "While he was sleeping in prison he woke up and said to some of his companions: while I was asleep a divine messenger (atin) came to me and said: "Allāh Almighty [decreed] to free you from the pain of the strokes!"”. He [the Sicilian] said: "Shortly after the ungodly Ibn al-Tiflì had him brought [before himself] and ordered that he be flogged, and he was flogged. When he returned to jail he was asked [what had happened] and he said: "By Allāh, truly, Blessed and Almighty Allāh relieved me of the pain of the flogging. I felt myself being struck, but I didn't feel any pain."
\end{abstract}

\title{
2. The story and its main characters
}

We have just seen a text referring to an unknown $q \bar{a} d \bar{l}$ of Sicily who was imprisoned and flogged for an apparently unknown reason. How could it relate to a specific context? What explanations can we try and give to this story? In the following paragraphs, I will attempt to formulate an answer to these questions through a detailed analysis of the historical context of Sicily, read and interpreted in the light of events that ran through political and religious life of the near North African coast.

\subsection{Ibrāhìm II and his "justice"}

This story took place at the time of Ibrāhìm II (261-289/875-902), the well-known Aghlabid who, more that any other emir of Ifrīqiya, has fired the imagination of historians and chroniclers in both the East and West. A controversial personality, he was guilty of committing serious crimes and yet, at the same time, he has been praised for his merits and his achievements.

The Arabic sources, which were generally written after the events they describe, create a biography of the emir that almost amounts to a hagiography, articulated in three different chronological periods: 1 . Pre-

${ }^{8}$ Cambridge, University Library, Qq. 235, f. 178v; ed. Abū 1-'Arab, Kitāb al-mihan, p. 465; for a reproduction of this manuscript, see figure 1; I would like to thank my colleagues Cristina La Rosa and Nuria Martínez de Castilla Muñoz for helping me to have access to the Cambridge manuscripts. 
destination; 2. Fall; 3. Redemption..$^{9}$ Ibrāhīm begins his reign in $261 / 875$, when he was still very young, in place of the legitimate successor Muhammad II Abū 1-Gharānīq, apparently thanks to the unconditional support of the masses, of the élites and of the fuqaha', who were the exponents of Mālikī Sunnism in Ifrìqiya. The emirate of Ibrāhīm begins with seven years of strict yet righteous government (875-882), followed by a despotic and authoritarian phase that intensifies with the arrival of the Fâtimid threat in Ifrīiya (280/893). During this period, the tyranny of the emir descends into folly, characterised by some melancholic traits. This arc of time ends with redemption (tawba) and the departure for jihad, which is, at the same time, a devotional act of pilgrimage (hajj) for all the sins committed, and concludes with the "martyrdom" in the way of Allāh during the siege of Cosenza (17 dhu l-qa'da 289/23 October 902). ${ }^{10}$

The passage considered here examines the theme of justice, or rather injustice, of Ibrāhīm II, focusing attention on the arbitrary nature of the punishment dealt out, and on the narrative dynamic in which divine intervention always relieves the suffering caused by punishment. ${ }^{11}$ As Annliese Nef acutely observed, justice is one of the fundamental rights of the kingship and the exercising of justice legitimises power; punishment itself is a representation of power, which is expressed through public, exemplary and sometimes spectacular rituals. ${ }^{12}$

Arabic sources describe Ibrāhīm II's constant concern for a righteous administration of the emirate and, as Mohamed Talbi writes: "Au cours de ses vingt-huit années de règne, durant la période heureuse comme durant la période la plus sombre, l'Émir montra ainsi un souci permanent d'assurer à son peuple une bonne et inattaquable justice. On verra plus loin qu'il ne s'octroyait qu'a lui seul le droit exceptionnel

9 Amari, Storia, II, pp. 62-118; Talbi, L'émirat aghlabide 184-296/808-909. Histoire politique, pp. 271-322; for a close reading of the biography of the emir, see Nef, "Instruments de légitimation politique".

${ }^{10}$ Talbi, L'émirat aghlabide, pp. 519-528; more recently see Di Branco, "Due notizie concernenti l'Italia meridionale dal Kitāb al- 'uyūn wa'l-hadā' iq fì ahbār al-ḥaqū' iq (Libro delle fonti e dei giardini riguardo la storia dei fatti veridici)," pp. 3-5.

${ }_{11}$ At the same time, the Andalusi chronicles underline the arbitrary nature of the punishment inflicted by the Umayyads and their leaders, where imprisonment frequently occurred without the intervention of a qā $d \bar{\imath}$ or a faqìh, see de la Puente, "En las cárceles del poder," p. 130.

${ }^{12}$ Nef, "Instruments de légitimation politique," pp. 85-88. 
d'être éventuellement injuste." ${ }^{13}$ It was an unlimited, and sometimes, inhuman form of justice, then, and one where punishment is often not in line with the crime committed; even notable figures of authority are not spared. Part of his attitude is evident in the choice of $q \bar{a} d \bar{\imath}$ and, as Talbi again writes, "il sut même faire taire ses ressentiments personnels dans son souci de donner à ses sujets, non seulement le meilleur Cadi, mais aussi celui qui avait leur confiance et leur assentiment". ${ }^{14}$

His obsession with justice remains throughout his reign, and Arabic sources inform us of his mental illness that progressively degenerated into total despotism, above all where the government was concerned, with an abuse of law and a general increase in horrifying crimes, which went as far as episodes of ritual cannibalism; Ibrāhīm has been accused of numerous crimes, which have consigned him to history as a "bloody monster," always prepared to kill relatives, courtiers, slaves and even any rank of state servants, without remorse or hesitation. Clearly we are presented with a historiographical picture that accentuates the traits of despotism, which were perhaps truly excessive, but which in any case are represented and described through complex historiographical interpretations that are often, though not always, hostile to the emir. ${ }^{15}$

\subsection{Ibn Tālib}

The Kitāb al-mihan relates that Ibn al-Majjānī was nominated as qā dì by Ibn Țālib, or 'Abd Allāh b. Țālib b. Sufyān b. Sālim b. 'Aqqāl b. Khafāja al-Tamīmī, a cousin of Ibrāhīm II. Ibn Ṭālib was a Mālikī judge, who already held the position of great $q \bar{a} d \bar{\imath}$ of al-Qayrawān when Ibrāhīm rose to power in 261/875. ${ }^{16}$ In the year 275/888-889 Ibn Ṭâlib fell from grace, following the scandal of Ibyāna, a rural property $5 \mathrm{~km}$ south east of Tunis, in the Mornag plain. Ibrāhimm wanted to acquire the land but the rightful owners opposed its sale; nonetheless the emir managed to take possession of it and at the same time, provoked an uprising

13 Talbi, L'émirat aghlabide, pp. 274-275.

14 Talbi, L'émirat aghlabide, p. 274.

${ }^{15}$ For a detailed analysis of the "criminal profile" of Ibrāhīm II in the light of source material and historiography, see Nef, "Violence and the prince: the case of the Aghlabid amīr Ibrāhìm II (261-289/875-902)".

${ }_{16}$ Abū 1-'Arab, Classes des savantes, pp. 220-221; Talbi, L'émirat aghlabide, pp. 272, 274-275, 315, 697-698. 
against the inhabitants, who turned to Ibn Țālib for justice. Ibn Ṭālib supported them and handed down his sentence, and so, by order of Ibrāhim, he was imprisoned, put on trial, tortured and killed, then replaced by his rival Ibn 'Abdūn. ${ }^{17}$

Where this study is concerned, it follows, first of all, that Ibn alMajjānī ruled from 261/875 until 275/888-889.

As Talbi notes, after the death of Ibn Tâlib, the despotic nature of Ibrāhīm increased once again; the emir did not dare to openly execute the great $q \bar{a} d \bar{l}$, but instead was concerned to find him guilty, parade him in a courtroom, feign his death and let him die naturally. ${ }^{18}$ But from this moment forward, Ibrāhim was no longer so scrupulous; after the trial and death of Ibn Țālib, a long series of executions of illustrious individuals followed, which came to a climax: one year later, in 276/889-890 Muhammad b. Hayyūn known as al-Barīdī, a young and talented secretary, fell from grace; in 277/890-891 Ibrāhim had the chamberlain Nașr b. al-Șamșāma killed, who just two years before had accompanied him to al-Qayrawān during the insurrection of the dirham; in 278/891-892 it was the Christian Sawāda al-Nașrānī that was executed, after he had rejected the management of the dìwān al$k h a r a \bar{j}$, which was offered to him on the condition that he converted to Islam, and undoubtedly the list does not finish here. ${ }^{19}$

\subsection{Ibn al-Tiflì}

Another character mentioned in the passage is Ibn al-Tiflì (or Ibn al-Tiffalī), ${ }^{20}$ who, at the command of Ibrāhīm, submitted the judge Ibn

17 Abū 1-'Arab, Kitāb al-mihan, pp. 279-280; L'émirat aghlabide 184-296/808-909. Histoire politique, p. 285; Mansouri, "Les 'ulamā' en rupture," p. 573.

18 Talbi, L'émirat aghlabide, p. 285.

19 Talbi, L'émirat aghlabide, pp. 285-286; Amari suggests that Sawāda could be one of the four Christian martyrs, John, Andrew, Peter and Anthony, who were imprisoned after the storming of Syracuse (878) and martyred by Ibrāhīm II, Amari, Storia, I, pp. 653654; II, p. 75.

${ }^{20}$ The vocalization of the name with fatha and tashdìd (Ibn al-Ṭaffalì), as proposed by the editor of the text, can be rejected in the light of the only copy of the manuscript, where a kasra clearly appears, Cambridge, University Library, Qq. 235, f. 178v, 1. 5; ed. Abū 1"Arab, Kitāb al-mihan, p. 465. The adjective tiflì means "enfantin, puéril" and also "argileux," this last meaning is connected to the "terre à foulon," cfr. Dozy, Supplement, II, pp. 48-49; for example a ghär al-tifl (or țfal or tafl) is documented in Sicily, which corresponds to the Latin spelunca crete in the jarìda of 1182, cfr. Cusa, I diplomi greci e 
al-Majjānī to torture; it would seem, in particular, that it was Ibn alTiflì himself who experimented with flogging using soaked roles of papyrus on Ibn al-Majjānī. In Sicily the nisba al-Tifli is also attributed to another individual who appears in the Kitāb al-amwāl of the Māliki jurist al-Dāwudī (who died between 402/1010-11 and 411/1020-21); the text relates the disputes that took place between $9^{\text {th }}$ and $10^{\text {th }}$ centuries over the possession of the fortress, al-qal ' $a$, of Agrigento. At one point in its Islamic period, definitely after 902 (the year of the conquest of Taormina by Ibrāhim II), the inhabitants of the fortress were expelled and the area was repopulated with new settlers, some of whom came from Ifrìiya; yet the former inhabitants laid claim to their rights and an unidentified ruler opened an inquest and listened to the parties:

There then rose the descendents of Agrigento who had been ousted from the fortress along with some early settlers who had survived and said to the ruler that the land was theirs and that he should remove the usurpers from there. The ruler enquired as to how the city belonged to them. Some elderly people said that they had purchased the land from a man called al-Tifli. The ruler of the period asked to sell to anyone willing to buy. Others said that the land belonged to them as they had bought it from Ibrāhīm ibn Ahmad. And that they had fought alongside him at Taormina and had received 6,000 [dīnārs] as fay' with which they had purchased it from him. The ruler then said: "By Allāh! Is there any deed or document in your possession?" They replied: "A long time has passed and we have nothing of that kind in our hands." He then said: "This land belongs to the whole community of the Muslims. I am not giving you this because of your claim."21

It is clear from this account that the former inhabitants laid claim to the fortress, which was acquired by a certain al-Tifli, clearly a public figure capable of initiating negotiations of this kind. At present it is not possible to establish with certainty the relationship between alTiflì and Ibn al-Tiflī (they could be father and son, or simply two un-

arabi di Sicilia, I, pp. 201, 242. It could be the case, although there are some strong doubts, that the name al-Tifli is a loanword of the Greek typhlos, "blind". Conversely, Adalgisa De Simone, who I would like to thank for her continued kind interest in my research, posits that the name al-Tiflì, which is mentioned in the Kitāb al-amwāl of al-Dāwudī, could be an adaptation of the Greek name Theophilos, cfr. De Simone, "In margine alla fiscalità islamica in Sicilia," p. 62.

${ }^{21}$ Al-Dāwudī, Kitāa al-amwāl, p. 55 (Arabic text), p. 94 (translation). The English translation of Sherfuddin is adapted with corrections by Alex Metcalfe, see $<$ http://medieval sicily.com/Docs/02_Islamic/al-Dawudi\%20on\%20Agrigento.pdf $>$ (accessed 05/03/2014). 
related individuals); yet, hypothetically speaking still, it may be possible to combine their names and roles with that of a certain al-Ṭāwuli, an individual whose name appears once in the Cambridge Chronicle..$^{22}$ The orthographic and phonetic similarities between the Arabic names al-Ṭiflì and al-Ṭāwulī are simple and quite clear, even though the identification of the two figures remains entirely provisional and hypothetical. The Cambridge Chronicle relates that in Palermo, in March 890, a revolt broke out, with Sicilians rising up against Africans:

In the year 6398 (889-890) the Sicilian people assaulted the people of Ifriquiya, and killed al-Ṭāwuli in the month of March (wa-fi sanat thamān wa-tis ìn tawaththabu al-șiqilliyyūn 'alà ahl Ifrīqiya wa-qatalū al-Ṭāwulī fì shahr mārshuh). ${ }^{23}$

In Amari's interpretation, Sicilians are local Arabs who rebelled against new troops sent from Ifriqiya, who came to the island both to lead the jihād and to try to put an end to the incessant riots that occurred in the island's capital. ${ }^{24}$ Incidentally, the Cambridge Chronicle refers to distinct "ethnic" factions that try to gain political and military rule of the island, though the precise identity and composition of these opposing forces has yet to be identified. ${ }^{25}$

Amongst the victims of the revolt led by people of Palermo, one finds al-Ṭâwulī, who is clearly one of the exponents of "African" power in the capital; as far as his role in Kitāb al-mihan is concerned, it can be supposed that he had assumed the role of wāli l-madina ("governor

${ }^{22}$ Cambridge, University Library, Dd. 5. 35(2), f. 3v, 1. 2. The so-called Cambridge Chronicle (in Arabic Ta'rìkh jazirat Siqilliyya or "Chronicle of the island of Sicily") is an anonymous work, compiled in Sicily in the second half of the 10th century and transmitted in two, apparently independent, versions, one Greek and the other Arabic; for the Arabic text see Amari, Biblioteca arabo-sicula, I, pp. 190-203; trans. I, pp. 224-236; for the Greek text, see Schreiner, Die Byzantinischen Kleinchroniken, pp. 326-340.

${ }_{23}$ Amari, Biblioteca, I, p. 193; trans. I, p. 226.

${ }^{24}$ The political climate seems to have engaged even the religious minorities; the Greek text of the Cambridge Chronicle relates that shortly before, in 886-887, Christians in Palermo were made to wear a distinguishing badge, see Cambridge Chronicle, in Schreiner, Die Byzantinischen Kleinchroniken, p. 334; Amari, Storia, I, pp. 571-572; Talbi, L'émirat aghlabide, pp. 498-499.

${ }^{25}$ The conflict between Sicilians and Africans is unique in historiography written in Arabic, which deals with the Islamic history of the island; it reappears, though, in Latin sources, which describe the conquest of the island by Normans, see Nef, "La désignation des groupes ethniques de la Sicile islamique dans les chroniques en langue arabe. Source d'information ou topos?," pp. 66-67. 
of the city; mayor"), or more probably of șăhib al-shurța ("chief of police"), as will be seen. ${ }^{26}$

If this hypothesis is correct, it would be possible to construct a chronological and political background to the events narrated in Kitäb al-mihan. In the first instance, it can be established that the torture of Ibn al-Majjāni occurred before 890, the year in which al-Ṭâwulì/Ibn al-Ṭiflì died.

Furthermore, we know from the text that the judge was nominated by Ibn Țālib, the cousin of Ibrāhīm who fell from grace in 888-889; as we have already noted, the torture of Ibn al-Majjāni can be clearly understood in the broader context of the destitution and violent persecution practised by Ibn 'Abdūn, the successor to and rival of Ibn Țālib. This phenomenon involves all the judges and magistrates nominated by him, even in the provinces of the Aghlabid emirate, from Tripoli to Sicily. ${ }^{27}$ It is very probable that the episode of Ibn al-Majjāni occurred between 888 and 890 , more precisely during $275 / 888-889 .^{28}$

As previously mentioned, al-Dāwudi mentions the sale of the fortress of Agrigento by a certain al-Tiflì, an episode that probably occurred in the age of Ibrāhim II (261-289/875-902). If we were to suggest that the three aforementioned individuals were a single person, that is Ibn al-Tiflì, al-Ṭiflì and al-Ṭāwulì, it would not be surprising if the latter, who came to Sicily as a representative of "African" power, in other words sent directly by Ibrāhīm II, had established his career (as $w \bar{a} l \bar{l}$ ?) repressing a judge supported by local power, selling the fortress of Agrigento, or beginning (arbitrarily?) the negotiations, which were then concluded, as the text indicates, more than ten years after by the same Ibrāhīm II in favour of the Banū 'Abd al-Ṣamad, following the victorious conquest of Taormina (902). ${ }^{29}$ Hypothetically speaking, it seems possible to believe that these episodes, together with

26 For the wāli l-madìna and the săhib al-shurța in the Aghlabid and Fātimid era, see Talbi, L'émirat aghlabide, p. 698; Dachraoui, Le califat fătimide, pp. 421-422; De Luca, Giudici e giuristi nella Sicilia musulmana. Notizie e biografie estratte dal Tartīb almadārik, pp. 25-26; for a comparison with the Iberian context in the age of the Caliphate, see de la Puente, "En las cárceles del poder," p. 106.

27 Abū 1-'Arab, Kitāb al-mihan, pp. 463-466; Mansouri, "Les 'ulamā' en rupture," pp. 573-574.

${ }_{28}$ The chronology of the whole paragraph suggests that the episode of Ibn al-Majjāni can be dated to before the death of Ibn Tālib, which occurred in 275/888-889, and was mentioned straight after the Sicilian event, Abū 1-'Arab, Kitāb al-mihan, p. 465.

29 On this last episode see Nef, "La fiscalité en Sicile sous la domination islamique," pp. $139,143-144$. 
other uknown measures (perhaps a certain tightening of financial pressure?), could have caused the insurrection of $888-889$, to which the Cambridge Chronicle alludes.

In the years that followed, the political climate in Sicily remained turbulent; Ibrāhīm nominated Abū l-Husayn Muhammad b. al-Faḍl as governor of the island in 278/891-892, though he only managed to reach Palermo the following year, on 2 safar 279/4 May 892, which indicates that the situation was still not calm. ${ }^{30}$ In Ifrīqiya, Ibrāhīm had to face a rebellion, which he quashed on 8 rajab 281/13 September 894 , triumphantly entering into Tunis; the chamberlain al-Hasan $b$. Nāqid was in charge of re-establishing order in Sicily too, but before attempting the crossing, a diplomatic mission was organised. ${ }^{31}$ Two famous Hanafi jurists were in charge of the mission, the $q \bar{a} d \bar{\imath}$ of Tunis Haytham b. Sulaymān and Qāsim b. Abì 1-Minhāl, who were sent to Sicily in the winter of $281 / 895$ :

During this year Haytham b. Sulaymān and Qāsim b. Abī 1-Minhāl departed for Sicily, [notwithstanding] the intensity of the cold and the strength of the winds. Ibrāhim b. Ahmad told them: "Make them aware of our strength, make them fear our punishment and [finally] grant them amnesty (amān)." They replied to him: "It is forbidden to sail the sea in a storm!," and [Ibrāhīm] replied: "It is vital that you leave in accordance with my horoscope". Ibn al-Jazzār said: “Abd Allāh b. Haytham told us that: When my father bid farewell to us, he said: My sons, I suggest you renounce the search of science (talab al- $\mathrm{ilm}$ ) and the social intercourse with its people! We would not have found ourselves in this regrettable situation if science and scholars ( 'ulam $\bar{a}$ ') didn't exist!'. And they drowned in the sea on the [...] Thursday dhu l-hijja (31 January-1 March 895). ${ }^{32}$

Despite the fact that the mission of the two Hanafi jurists evidently ended at sea, ${ }^{33}$ al-Hasan b. Nāqid arrived in Palermo between 1 Sep-

30 "Year 278 (15 April 891-2 April 892)... In this same year, Muhammad b. al-Faḍl governed Sicily;" "Year 279 (3 April 892-22 March 893) In this year Muhammad b. alFadl governed Sicily; the latter entered Palermo, the capital of the island, on the second of the month of șafar (4 May 892)," Ibn 'Idhārī, al-Bayān al-mughrib, in Amari, Biblioteca I, p. 416; trans. II, p. 467.

31 Amari, Storia, I, pp. 572-573; Talbi, L'émirat aghlabide, pp. 499-501.

${ }^{32}$ Kitāb al-'uȳūn, ed. al-Sa'î̀ī, I, p. 84; Talbi, L'émirat aghlabide, p. 500.

33 Talbi states that "les deux faqīhs firent la traversée un certain jeudi de Dhū 1-Hijja 281 /fevrier 895 ," yet the verb used is gh.r.q, which clearly means "être plongé tout entier dans l'eau, être submergé," or better "se noyer, périr à la mer (se dit des hommes ou des navires)," Biberstein Kazimirski, Dictionnaire arabe-français, II, p. 459; Talbi, L'émirat aghlabide, p. 500, followed by Chiarelli, A History of Muslim Sicily, p. 291 ("From all accounts they succeed in bringing the matter to a peaceful conclusion"). 
tember 895 and 18 February $896 .{ }^{34}$ It is interesting to note that Haytham b. Sulaymān interprets a famous hadith of the Prophet, ${ }^{35}$ laying the main blame for their fall from grace at the search of science and the social intercourse with sages (mujālasat al- 'ulama' '), factors that probably played a role in their appointment; not least, the two Hanafi jurists were probably nominated for being leading exponents of a then "dominant" juridical school in Ifrīqiya and Sicily, which will be analysed in more detail further on.

\subsection{Ahmad b. Muhammad al-Ṭà'̄, known as Ibn al-Majjānì}

The main character of this story is a judge, Ahmad b. Muhammad al-Ṭầ' $\overline{1}$, better known as Ibn al-Majjānī, a laqab who declares his North African origins, from Majjāna, a city in Ifrīqiya of some standing in the Aghlabid era. ${ }^{36} \mathrm{Ibn}$ al-Majjānī does not appear in other sources and consequently is unknown to historiography; even though it is not made explicit in the text, Ibn al-Majjānī held the role of $q \bar{a} d \bar{\imath}$ of Sicily, supporting the Aghlabid governor of the island (wāli ), an extremely important role. In theory, every city or district of the Aghlabid emirate had its $q \bar{a} d \bar{l}$, who was nominated directly by the great $q \bar{a} d \bar{l}$ of Ifrìiya; the latter had a seat in al-Qayrawān and his election or removal depended on the will of the emir, who could consult the fuqah ${ }^{\prime}{ }^{37}$

The $q \bar{a} d \bar{l}$, the custodian of a strong Islamic juridical culture founded on the Qur'ān and the Sunna, was in charge of resolving conflicts, in accordance with the figh and based on his own personal interpretation (ijtih $\bar{a} d)$; he sat in the mosque, listening to complaints, passing judgement and ensuring that punishment was implemented. His tasks were not strictly limited to the judicial: he monitored how shari ' $a$ was ob-

34 "In the year 6404 (895-896) the truce was signed between the Muslims and the Rüm at the time [of the government] of Abū 'Alī [al-Hasan b. Nāqid]," Cambridge Chronicle in Amari, Biblioteca, I, p. 193; trans. I, p. 227; Talbi, L'émirat aghlabide, p. 500 and no. 4.

${ }^{35}$ Ut tubū l-'ilm wa-law bi-l-Ṣ̂n fa-inna talab al- 'ilm farìda 'alà kull al-muslim, "Look for science, even in China; scientific research is a duty for every Muslim!," on this see Bernards, "Talab al- 'ilm amongst the linguists of Arabic during the "Abbasid period".

36 Fenina, "La ville de Mağğāna sous Ziyādat Allāh I: un atelier monétaire peu connu et une principauté éphémère à l'époque ag̉labide". On the Majjāna, particular individuals or communities, living through North Africa and related problems see Amara, "L'Islamisation du Maghreb central (VII'-XI' siècle)," pp. 121-122.

37 Dachraoui, Le califat fătimide, p. 416; De Luca, Giudici e giuristi, pp. 39-40. 
served, which was not just a rule of law, but also a style of spiritual and temporal life. This means that his remit was in some ways unlimited: it encompassed cultural traditions and all aspects of public and private life. ${ }^{38}$ In every Islamic society the $q \bar{a} d \bar{\imath}$ was also called to determine the distribution of land, contracts, taxes, the division of profits and the fate of prisoners; it was, then, a crucial office, particularly in a "growing frontier" like that of Sicily in the Aghlabid and Fātimid era. ${ }^{39}$

Ibn al-Majjānī was already in jail when he was punished by being beaten with strokes of soaked rolls/ropes of papyrus (bi-tawāmìr alqarâțìs al-mablüla), ${ }^{40}$ a fact that immediately brings to mind the area of Palermo where papyrus grew and it was used to make rolls (tamür), used to make sheets for the Sultan, and above all it was bound in ropes used for ships, according to Ibn Hawqal; it goes without saying that the soaked rigging of ships represented, without any doubt, a dreadful means of torture. ${ }^{41}$

It is not known whether the punishment took the form of a corporal penalty $(h a d d)$ or more probably an arbitrary one ( $t a$ ' $z i \bar{r})$, since both involved flogging and imprisonment. ${ }^{42}$ Unfortunately the extent of the crime committed is not known either, though it can, in any case, be included in the more or less arbitrary repression carried out by Ibn 'Abdūn on behalf of Ibrāhīm II, following the trial of Ibn Ṭālib (275/888-889). However, the type of prison can perhaps help to clarify the role of the prosecutor Ibn al-Ṭiflï; indeed, Muslim jurists distinguish

38 On the figure of the $q \bar{a} d \bar{\imath}$ in Aghlabid and Fātimid Ifrīqiya see Talbi, L'émirat aghlabide, p. 697; Dachraoui, Le califat fâtimide, pp. 404-416; for more general studies, see Tillier, Les cadis d'Iraq et l'État abbasside (132/750-334/945)and the contributions in El Hour and Mayor (ed.), Cadies y cadiazgo en al-Andalus y el Magreb medieval.

${ }^{39}$ Granara, "Islamic Education and the Transmission of Knowledge in Muslim Sicily," pp. 163-164.

${ }^{40}$ The word qirțās (plural qarātīs) means "sheet or roll of papyrus," "parchment" or "paper," see Gacek, The Arabic Manuscript Tradition. A Glossary of Technical Terms \& Bibliography, p. 114.

41 "Yonder there is still a low-lying area entirely covered with papyrus (barbir), or rather bardī, which is [the plant] from which they make the tumāa (rolls of paper on which to write). I do not know if Egyptian papyrus has on the face of the earth another type other that this in Sicily. The latter for the most part is bound in ropes, used for ships, and some is used to make sheets for the Sultan, however many he needs," Ibn Hawqal, Sürat al-ard, in Amari, Biblioteca, I, pp. 16-17; trans. I, p. 21; Ibn Ḥawqal, Șürat al-ard, ed. Kramers, I, pp. 122123; Ibn Hawqal, Configuration de la terre, French Trans. by Kramers and Wiet, I, p. 121.

${ }^{42}$ Hentati, "La prison en Occident musulman medieval," pp. 151-160; for the Andalusi case, see de la Puente, "En las cárceles del poder," p. 124. 
between two types of prison, one being the prison of the judge (habs $a l-q \bar{a} d \bar{\imath})$, designed for protective custody or administrative detention whilst prisoners awaited corporal punishment, where debtors were mainly held. The other was the political-military prison, where thieves and assassins (habs al-lușuss) were kept; it was managed by governors or by the șăhib al-shurța, the chief of police who oversaw the prosecution of criminals, for both protective custody and long-term detention. ${ }^{43}$

This distinction seems to have been followed in Fātimid Ifrīqiya; indeed in the time of Mahdī 'Ubayd Allāh, a prison of criminal law existed (bayt al-dam, "the house of the crimes of blood") where the thieves/lușus and criminals guilty of homicide were detained; this was distinct from a prison of civil law where every type of prisoner was kept. ${ }^{44}$ Clearly this theoretical distinction in the management of prisons was, in practice, also a cause of conflict between governors and judges ${ }^{45}$ and there were several cases, for example in 'Abbāsid Baghdad, where the men condemned by the $q \bar{a} d \bar{l}$ were sent to a prison presumably dependent on the shurta. ${ }^{46}$

Where this present study is concerned, a political-military prison is well-suited to the case of Ibn al-Majjānī and would fittingly explain the intervention of Ibn al-Ṭiflī who could in fact be the șăhib al-shurța, who was in charge of carrying out the punishment inflicted by the Aghlabid emir. ${ }^{47}$

Little is known about the location of the prison; assuming that it was in Palermo though, one prison was mentioned by the monk Theodosius, who was imprisoned in the city after the conquest of Syracuse

43 This distinction was proposed by the jurist al-Khassāf (d. 261/874) and followed by Ibn al-Qāșs (d. 335/946), see Schneider, "Imprisonement in Pre-Classical and Classical Islamic Law;" Hentati, "La prison en Occident," pp. 175-176; Tillier, "Prisons et autorités urbaines sous les Abbasides," pp. 388, 392-394; Tillier, "Vivre en prison à l'époque abbaside," pp. 636, 643, 655; Tillier, "Les prisonniers dans la société musulmane (II'/VIII"$\mathrm{IV} / \mathrm{X}^{\mathrm{e}}$ siècle)".

${ }^{44}$ Hentati, "La prison en Occident," p. 175. The distinction is rather theoretical; for example, in the evidence of the Andalusi documentation from the age of the Caliphate, the administrative prison is not mentioned, see de la Puente, "En las cárceles del poder," p. 130.

${ }^{45}$ Hentati, "La prison en Occident," p. 177; Tillier, "Prisons et autorités," p. 396.

46 Tillier, "Prisons et autorités," p. 394.

47 The săhib al-shurta was among the highest officials in both central and provincial government, "when the sạhib al-shurta was powerful he could trespass extensively on to jurisdiction of both hisba and that of the $q \bar{a} d \bar{l}$, taking charge of enforcing proper conduct in public places, dispensing criminal justice and supervising the implementation of retaliation or qișās," Marín, "Shurța," p. 510. 
in 878 , where he had occasion to march through the city with the bishop of Syracuse, and briefly relay his impressions. As he waited for the verdict, Theodosius was locked in an underground prison, which recalls the well-known Mutbaq in Baghdad: ${ }^{48}$

Tandem in desmoterium coniicimur. Id autem lacus est, quattuor supra decem gradibus depressum habens pavimentum. Adeo ut illi ostiolum pro fenestra esset. Tenebrae hic mirae et palpabiles; lumine tantum lucernae, vel interdiu, aliqua ex parte collustratae. Neutiquam in isto carcere luciferum mane exorientem fas est aspicere, nec lunam radios emittentem. Corpusculum hic aestivis caloribus hic percussum (aestas enim erat) et cohabitantium halitu torridum. Praeterea cimices et pediculi et pulicum examina, ceteraque hisce bestiolis similia, per tenebricosum hoc pavimentum, misellum hominem stigmatiam reddunt. Sunt et eodem in carcere conclusi, promiscueque nobiscum harum miseriarum mercaturam facientes Aethio, pes, Tharsenses, Arabes, Hebraei, Longobardi, tum Christiani nostrates e diversis locis profecti; in queis erat quoque sanctissimus Militensis episcopus, duabus compedibus pedes obitrictus. ${ }^{49}$

The association between the palace/castle, as a seat of power, and the prison, follows a rather well-known Islamic model which can also be found in Bașra (from 17/638) and Baghdad, as well as in Cordoba under the Umayyads. ${ }^{50}$ A prison - though it is not known if it is the same one - is enclosed in the castle in Palermo, which was the seat of Ibn Qarhab (300-304/913-916), presumably on the old acropolis of the city, which is the current site of the Royal Palace; here, Ibn Qarhab had imprisoned the $q \bar{a} d \bar{l}$ Ishạa $\mathrm{b}$. Abī Minhā $l,{ }^{51}$ and he himself was impris-

48 The Muṭaq, literally "the cover," was the main prison in 'Abbāsid Baghdad, which was in use from 145/762-763 until after 272/885; the term has come to mean an underground prison made of pits and underground chambers, some of significant size, Hentati, "La prison en Occident," p. 180; Tillier, "Vivre en prison," pp. 403-406. It is also worth noting the sijn al-mutbaq of the Alcázar in Cordoba and the Iberian types, for which see de la Puente, "En las cárceles del poder," pp. 113-120.

49 Epistola Theodosii monachi de excidio Syracusarum, II, p. 276; on the epistle and the complex tradition of the work see also Amari, Storia, I, pp. 541-551; Zuretti, "Italoellenika [1]. La espugnazione di Siracusa nell' 880 . Testo greco della lettera del monaco Teodosio", pp. 172-173; Anastasi, "L'epistola di Teodosio monaco," p. 177; Lavagnini, "Siracusa occupata dagli Arabi e l'epistola di Teodosio monaco;" Rognoni, "Au pied de la lettre? Réflexions à propos du témoignage de Théodose moine et grammaticos sur la prise de Syracuse en 878," pp. 219-224.

50 Tillier, "Prisons et autorités," pp. 398, 400; de la Puente, "En las cárceles del poder," pp. 113-120.

51 "During the year [304/916-17] the attitude of the jund and the Berbers towards [Ibn Qarhab] in Sicily became hostile, such that they beseiged him in his castle (qașr), where they placed Isḥāq b. Abī Minhāl, after the latter was held in chains in his prison. This man 
oned, probably in the same place, with his son and the $q \bar{a} d \bar{l}$ Ibn alKhāmī, waiting to be transferred to Sūsa in the presence of al-Mahdī. ${ }^{52}$

A prison enclosed in the palace, known as the government's prison (habs al-sultān), and thus a political-military jail, would seem to be explicity mentioned in the descriptions of the Kalsa district $(<$ Ar. $a l-K h \bar{a}-$ lișa), the headquarters of Fạtimid power in Sicily, in accordance with the wishes of the Fātimid governor Khalīl b. Ishāa in 326/937-938..$^{53}$

The letters of Geniza also mention a prison in a fortification in Palermo, probably the same one on the acropolis, where a certain Bundār was imprisoned around 970; a freed slave of Palermo, Bundār went on to leave a quarter of his property to the poor in Jerusalem, in accordance with Islamic law. ${ }^{54}$ In August 1056, the noted judge (dayyān) of Palermo Mașli' ah ben Eliyya was held in prison for three days; he was an active merchant and was found guilty of trying, together with his

[the judge] drew up the inventory of the man [Ibn Qarhab] who had with him goods, clothing and weapons. And so prisoner, together with his son, was transferred to Mahdī in Sūsa," Kitāb al-'uȳun, I, p. 187; "Then the jund and the Berbers rebelled against him, shut him in the castle in Palermo (Siqilliyya), let Abū 1-Minhāl out of the prison and took him to the castle, where he laid out the inventory of goods, weapons, clothes and more that had been found in muharram 304 (5 July-3 August 916)," Ibn al-Khațīb, A'māl al-a 'lām, p. 476 (Arabic text); Amari, Storia, II, pp. 183-184 no. 2 (Italian trans.). Ibn Abī Minhāl had already been qā dì in Sicily at the time of the two Ibn Abī Khinzìr brothers, see Ibn Khaldūn, Kitāab al-'ibar, in Amari, Biblioteca, II, p. 529; trans. II, 882; he was later named $q \bar{a} d \bar{l}$ at Qayrawān from 307/919 until 311/923, and later from 312/924 until his death; for the story of Ibn Qarhab see Mandalà, "Una nueva fuente para la historia de la Sicilia islámica. La revuelta de Aḥmad Ibn Qarhab (300-304/913-916) en un pasaje de al-Muqtabis V de Ibn Ḥayyān," pp. 343-374.

52 "Ibn Qarhab then thought of setting sail for al-Andalus; he bought ships and loaded many things, but the Sicilians subverted his plan; they took everything he had put on the ships; they imprisoned Ibn Qarhab with his son and his qā dì called Ibn al-Khāmī; they put chains on their feet, and [thus] sent them to "Ubayd Aliāh," Ibn 'Idhārī, al-Bayān almughrib, in Amari, Biblioteca, I, pp. 419-420; trans. II, p. 471.

${ }_{53}$ Ibn Hawqal, Sürat al-ard, in Amari, Biblioteca, I, p. 12; trans. I, p. 14; nonetheless the edition by Kramers offers the variant jayš li-l-sultāan ("the ruler's militia"), see Ibn Hawqal, Sürat al-ard, ed. Kramers, I, p. 119; Ibn Hawqal, Configuration de la terre, French trans. by Kramers and Wiet, I, p. 118. A fatwà of al-Ḍābit al-Ṣafāqusī (d. 543/1148) distinguishes between the prison of the qā $d \bar{\imath}$ and the prison of the sultân, see Hentati, "La prison en Occident," p. 176.

${ }^{54}$ We-noqaš be-mahamorot ha-meșuda, "prisoner in the grottoes of the fort;" Šemu'el b. Hoša'na, the head of the Palestine Academy, was in charge of the transfer of Bundār's money, see Ben Sasson, The Jews of Sicily (825-1068), doc. 32, pp. 143-144; Simonsohn, The Jews in Sicily, I, doc. 26, pp. 17-18: 17; Gil, "Sicily 827-1072, in light of the Geniza documents and parallel sources," p. 150, no. 21. For the prison in the Royal Palace of Palermo see Purpura, "Graffiti di navi normanne nei sotterranei del Palazzo Reale di Palermo;" Longo, La fabbrica medievale, pp. 76-77. 
partners, to cheat the Islamic financial system in the city, by not paying the tithe (al- 'ushr) on imported goods. ${ }^{55}$ Nothing is known of this latter prison, which would be similar to the type of the so-called prison of the judge, which we noted before.

Finally, it is interesting to note one element of the story, that is the supernatural intervention that alerts the judge to the impending suffering; this is the dreamlike vision of attin, a celestial messenger, whose act of redeeming intervention is also mentioned in another passage of the Kitāb al-mihan: Tawba al-'Anbarī al-Bașrī (d. 131/748), while he was in prison, dreamt he was visited by one of these celestial creatures who taught him an invocation $\left(d u^{\prime} \bar{a}^{\prime}\right)$, thanks to which he gained freedom from the prison. ${ }^{56}$

\section{Sicily under the religious and juridical-doctrinal control of Ifriqiya $\left(9^{\text {th }}-\right.$ first half of the $10^{\text {th }}$ century)}

\subsection{Juridical schools and magistrature in Ifrìqiya}

In Ifrīqiya, at the beginning of the $3^{\text {rd }} / 9^{\text {th }}$ century, the Mālikì/Hanafi dualism was still in its early stages, and one cannot talk in terms of a "conflict" between the different juridical schools; the co-existence of two different approaches was resolved with the nomination of two qā $\bar{i} \mathrm{~s}$ in Ifrìqiya, both of whom were resident in the capital al-Qayrawān: one was Asad b. al-Furāt, a pupil of Mālik and the future conqueror of Sicily, who oscillated between the Mālikī and Hanafì schools, and was $q \bar{a} d \bar{\imath}$ from 818 or 819 until 829; the other was Abū Muhriz, a Hanafi (though Mālikī according to others), qā dị from 806 until 829. ${ }^{57}$ From

${ }^{55}$ Ben Sasson, The Jews of Sicily, doc. 87, pp. 406-416: 410; Simonsohn, The Jews in Sicily, I, doc. 109, pp. 224-229: 228; Gil, "Sicily 827-1072," pp. 142-144.

56 Abū 1-'Arab, Kitāb al-mihan, p. 404; p. 169 (for Tawba's story). On the topic of dreamlike visions and divine interventions, it ought to be noted that following a battle, perhaps at Caltavuturo (268/881-82), a fallen soldier, Abū 'Abd al-Salām Mufarraj, saw the hür al- 'ayn (in the text jawärin, "young girls") descend from the heavens and look for martyrs of the jihād to take with them, see al-Mālikī, Riyầ al-nufüs, in Amari, Biblioteca, I, pp. 227-38; trans. I pp. 259-260; Amari, Storia, I, pp. 562-564; Talbi, L'émirat aghlabide, p. 494. For more on dreamlike visions and angels in Islām see Lory, Le rêve et ses interprétations en Islam, pp. 145-149.

${ }^{57}$ Rizzitano, "Asad b. al-Furāt faqīh e qā dì d'Ifrīqiya;" Rizzitano, "Il contributo dei musulmani di Sicilia alla diffusione del fiqh mầlikita," pp. 479-481; Idris, "L'aube du ma- 
250/848, after the nomination of Sahnūn as $q \bar{a} d \bar{l}$ of Ifrīqiya, the position of the Mālikis strengthened, to the detriment of Hanafism, and it began to gain significant popularity amongst the Maghribī masses, due in part to the activism of the numerous pupils of the master, who had come to listen to his teachings from the Maghrib and al-Andalus (they numbered around four hundred according to the sources).

In the second half of the $9^{\text {th }}$ century, there was a gradual affirmation of Mālikism, a historical phenomenon whose roots can be found, according to Ibn Khaldūn (732-808/1332-1406), first in the strict adherence of the Maghribī and Andalusī badāwa to the thinking of Mālik, and to the severe traditionalism of Medina, which at the same time separated them markedly from the hadāra of the 'Irāqī school, and second in the strong influx of "Westerners" (Maghribīs and Andalusīs) who had returned to their homelands, having studied in Medina under Mālik and his pupils, avoiding 'Irāq in the course of their education. ${ }^{58}$

At the time of Ibrāhim II, the Aghlabid court was in favour of the Hanafis, particularly if they were of Mu'tazili tendencies, while the general population supported the Mālikìs; during the reign of Ibrāhīm II the first $q \bar{a} d \bar{l} l$ l-qudàt was Ibn Tâalib, as previously noted; in 275/888889 Ibrāhīm nominated Ibn 'Abdūn, a Ḥanafì and Mu'tazilī scholar, known for his rigidity towards the Mālikīs. In 280/893 Ibn 'Abdūn was replaced by 'Īsà $b$. Miskīn, a figure equally renowned for his anti-Mālikī thought, who held the position until the end of his reign. ${ }^{59}$ In rajab 289/June 902, before leaving for the jihād in Sicily, Ibrāhīm handed the role of $q \bar{a} d \bar{l} l-q u d \bar{a} t$ to Muḥammad b. Aswad b. Shu'ayb al-Șiddinī, a Hanafi and Mu'tazilì scholar, who soon dedicated himself to the per-

likisme ifrīqiyen," pp. 34-40; Talbi, "Theological Polemics at Qayrawan during the $3^{\text {rd }}-9^{\text {th }}$ century;" De Luca, Giudici e giuristi, pp. 33-34; Tsafrir, The History on Islamic School of Law. The Early Spread of Hanafism, pp. 103-115; Brockopp, "Asad b. al-Furāt;" Nef, "Comment les Aghlabides ont décidé de conquérir la Sicile...," pp. 204-205.

58 Ibn Khaldūn, Kitāb al- 'ibar, I, pp. 805-806; Ibn Khaldūn, Les prolégomènes, French trans. by MacGuckin de Slane, III, pp. 14-15. Moreover, according to H.R. Idris, one of the main elements in the increasing popularity of Mâlikism was the North African attachment to the Mālikī school, which was considered "local" and was consequently used as a tool by the Maghribi "bourgeoisie," who wished to assert themselves against Hanafism, which was followed by the élites, see Idris, "Reflexions sur le malekisme sous les umayyades d'Espagne," pp. 410-414; De Luca, Giudici e giuristi, pp. 36-37.

${ }_{59}$ 'Īsà b. Miskīn b. Manșūr b. Jurayj b. Muhammad al-Ifrīqī (d. 275/888), a famous jurist, on whom see al-Khushanī, Classes des savantes, pp. 227-229; al-Qāḍī 'Iyāẹ, Tartīb al-madārik wa-taqrīb al-masālik fì ma 'rifat a 'lām madhhab Mālik, ed. Aḥmad Bākir Mậmūd, II, pp. 212-228; De Luca, Giudici e giuristi, p. 58, no. 42. 
secution of the Mālikīs. After the death of Ibrāhīm II (289/902), the situation changed in favour of the Mālikis. Due to the unhappiness of the population, during 290/903, the successor Ziyādat Allāh III opted for Mālikism, nominating Hiimās b. Marwān b. Simāk al-Hamdānī, who was one of the pupils of Sahnūn; to satisfy the desires of the court, the Hanafī Muḥammad b. 'Abd Allāh b. Jimāl was nominated qāộ̀ in Raqqāda, in spite of the protests of Himās, who in 294/906 (or 295/907) managed to remove him from office.

As Paul E. Walker intelligently observed, on the eve of the victory of the Fātimids, religious culture of the Aghlabid emirate was controlled by elements of both madhhabs, Mālikī and Hanafì, whose exponents were active in the main urban centres. ${ }^{60}$ Although both belonged to the Sunni orthodoxy, their respective doctrines were the subject of bitter debate and rivalry, especially when a Hanafi authority had recourse to a Mu'tazili theological position (the sources note this tendency, relating that the individual in question referred to the "creation of the Qur'ān").

When the Fâtimids defeated the Aghlabid dynasty and took possession of Ifriqiya, it seemed that their intelligentsia was not at the same doctrinal or theological level as that of their Māliki jurist rivals; the Fātimids began heavily repressing the Mālikī madhhab in Ifrīqiya and, according to Monès, this provoked an adverse reaction that resulted in a defeat of the Shī ${ }^{6}$ a and the triumph of Mālikism. ${ }^{61}$ Furthermore, with the advent of the Fattimid da'wa in the Maghrib, one witnesses the change from Hanafism to Shī'a amongst the Aghlabid élites; Qāḍi al$\mathrm{Nu}$ 'mān cites various cases of "conversion" to Eastern doctrines (tashri $q$ ), a choice motivated in part by the desire to forge a career in magistrature; a case in point is the aforementioned Ibn 'Abdūn - the master of the famous Fātimid $d \bar{a} \mathfrak{c} \mathrm{l}$ Ibn al-Haytham - who remained faithful to the Hanafi school, but took pride in the success of his Shī'i pupils. ${ }^{62}$

The end of the Shī'a in Ifriqiya coincided with the political rift between the Zìrids and Fātimids at the time of al-Mu'izz b. Bādīs, and in

${ }^{60}$ Walker, "Introduction," pp. 22-23.

${ }^{61}$ Monès, "Le malékisme et l'échec des fătimides en Ifrīqiya;" De Luca, Giudici e giuristi, pp. 42-43; Granara, "Islamic Education," p. 152; for an analysis of the thesis of Monès see Dachraoui, Le califat fătimide, p. 399.

${ }^{62}$ Dachraoui, Le califat Fătimide, pp. 400-402; Madelung, "The Religious Policy of the Fātimids towards their Sunni Subjects in the Maghrib," pp. 98-99. 
407/1016-17 the Mālikī 'ulamà' incited the masses to eliminate the Shi' ${ }^{\prime} 1$ communities present in the country. ${ }^{63}$ From the second half of the $11^{\text {th }}$ century the triumph of Mālikism over Hanafism in North Africa is well documented, but it can be read in different ways; politically, it can be seen as a victory for the jurists over their rulers; socially and economically, it can be understood as an act of uprising of the masses against the élites; from the theological perspective, it can be read as a victory of the Mālikî jurists over those who made use of theological reasoning, like the Mu'tazila or the Shī'a. ${ }^{64}$

\subsection{Magistrature in Sicily}

The information on judges active in Sicily during the Aghlabid and Fātimid period is scarce and incomplete, but facts on Sunnī and Mālikî judges and jurists can be gleaned from the main North African biographical dictionaries: Abū 1-'Arab, al-Mālikī, al-Khushanī, Ibn Nājīi, Ibn Farhūun, al-Qāḍ̂̀ 'Iyāẹ and so on. ${ }^{65}$

Without doubt, from the six profiles briefly outlined here (see below 5. Appendix), Sicily appears as a land of Māliki preaching, ${ }^{66}$ these "Sicilian" judges were individuals of considerable personal experience, well-trained in Mālikî law and connected with the school of Sahnūn and his pupils. They are always nominated in Ifrìiya and it closely reflects the political events there. Nonetheless, it is important to also consider that the "Sicilian" biographies mentioned above come from Sunnī-Mālikī sources, and therefore lack another documented source that would allow for the elaboration of other historiographic perspec-

${ }^{63}$ Madelung, "The Religious Policy," p. 97.

${ }^{64}$ A watershed moment would come with the rift, around 439/1047-48, between the Zìrid al-Mu'izz b. Bādīs and the Fāțimids, and the consequent official adoption of the Mālikì doctrine, see Idris, "Reflexions sur le malekisme," p. 399; Granara, "Islamic Education," p. 157.

${ }^{65}$ Amari, Storia, II, pp. 255-262, 542-562; Rizzitano, "Il contributo dei musulmani;" al-Dūrī, Siqilliyya. 'Alāqātu-hā bi-duwal al-bahr al-mutawassit al-islāmiyya min al-fath al- 'arabì hattà al-ghazw al-nūrmandī, pp. 179-190; De Luca, Giudici e giuristi, pp. 7-47, 50; Granara, "Islamic Education," pp. 162-167; Chiarelli, A History, pp. 290-296.

${ }^{66}$ Particularly instructive is the example of Abū Sa'î̀d Luqmān b. Yūsuf al-Ghassāni who died in Tunis in 318/930-31; he was the pupil of 'Abd al-Jabbār, 'Īsà b. Miskīn and Yahyà b. 'Umar, and spent fourteen years in Sicily teaching the Mudawwana, al-Mālikī, Riyāẹ al-nufūs, in Amari, Biblioteca, I, pp. 223-224; trans. I, pp. 256-257; al-Qāḍī 'Iyāḍ, Tartìb al-madārik, II, pp. 311-313; De Luca, Giudici e giuristi, pp. 62-65. 
tives ${ }^{67}$ For example, in the early days of the island's conquest, a fleeting mention of Ibn 'Idhārī reveals that Ahmad b. Abī Muhriz, the son of the aforementioned Hanafĩ qa $\bar{a} \bar{l}$ Abū Muhriz al-Kilābì (incumbent in al-Qayrawān, from 203/818-819 until 214/829), briefly used the judiciary in Sicily, shortly before his death in 221/836 (in 220/835 he was nominated $q \bar{a} d \bar{\imath}$ of Ifrīqiya). ${ }^{68}$

Undoubtedly many questions remain unanswered; for example one can ask, did the repression of the Mālikī school enforced by Ibrāhīm II in Ifriqiya have a direct repercussion in Sicily too? And if the answer is in the affirmative, is it possible to read the case of Ibn al-Majjāni in the light of this understanding? Furthermore, did the rift between the Mālikism and Shī'a that occurred in Ifriqiya around 407/1016-17 have a political and religious impact on Sicily? Finally, an important question remains, that is, what are the historic events that permitted the Mālikī school to become established in Sicily?

\section{Conclusion}

As William Granara notes, in the $11^{\text {th }}$ century, at the end of its Islamic history, religious life in Islamic Sicily was Sunnī-Mālikī and was well integrated into the dār al-Isläm. ${ }^{69}$ For example, one of the most famous Sicilian scholars was Abū 'Abd Allāh Muhammad b. 'Alī b. 'Umar al-Māzarī (d. 538/1138), an eminent Mālikì jurist, a scholar of the hadith, a theologian and Ash'ari preacher. ${ }^{70}$ Ash 'arism seems to have made a comeback in the island - even though to a lesser degree than some Eastern seats - according at least to the statement of Ibn Hazm (d. 456/1064): "as far as the sect of the Ash'aris (al-ash 'ariyya) is concerned, they flourished in Baghdad and Bașra; then they traded

${ }^{67}$ For a careful consideration of this see Tsafrir, The History, pp. 103. See also the different perspectives opened up by the study of Ibāḍi sources, see Chiarelli, "The Ibāḍìyah in Muslim Siciliy;" Chiarelli, "The Ibāḍi Presence in Muslim Sicily" and for a general overview see Chiarelli, A History, pp. 290-301.

${ }^{68}$ Ibn 'Idhārī, al-Bayān al-mughrib, ed. Colin and Lévi-Provençal, I, pp. 105-106; Ibn al-Haytham, Kitāb al-munāzarāt, p. 160 and no. 163; Chiarelli, A History, p. 290.

${ }^{69}$ Granara, "Islamic Education," p. 151; see also the list of scholars on pp. 165-167.

${ }^{70}$ Idris, "L'école mālikite de Mahdia. L'imām al-Māzarī (m. 536 H/1141);" Borruso, al-Imàm al-Màzari. Un mazarese del medioevo arabo-islamico; Granara, "Islamic Education," p. 170. 
in Sicily, in al-Qayrawān and in al-Andalus, and so [there] their influence dimmed, thanks be to Allāh, Lord of the worlds!". ${ }^{71}$

It is worth noting, however, that contemporary historiography, because it is based on information that is unilateral in outlook, has projected the success of Mālikism on the whole of Islamic history in Sicily, from its origins (827) until the Norman conquest (1061-1089). ${ }^{72}$

Where the $10^{\text {th }}$ century is concerned, some statements would seem to portray a different reality, or perhaps simply a more complex one; for example, al-Muqaddasi (who completed his work in 375-378/985988), while describing Kalbid Sicily, declares openly and without hesitation: "Most people of Sicily are Hanafi" (wa-akthar ahl Ișilliyya hanafiyyūn, or according to a variation wa-l-ghālib 'alà Isqilliyya așhāb $A b \bar{\imath}$ Haniffa "the majority [of those who live] in Sicily follow Abu Hanifa") ${ }^{73}$ it is not known to which "Sicilians" the geographer and traveller is referring, whether to an Islamic 'ämma or rather to a khāsșa present in the island. Nevertheless, in the light of what has already been said above, the success of the Hanafi madhhab in Sicily can be interpreted as the fruit of the anti-Māliki political religion promoted by the last Aghlabids, subsequently enforced by the Fătimid caliphate of Ifrīqiya and, in another way, perhaps also by their Kalbid governors. ${ }^{74}$

It should be noted too that the same al-Muqaddasi also confirms that the Mālikī school was solidly established only in al-Andalus, ${ }^{75}$ while in the Maghrib, though it held a majority, it still competed with the Hanafi school, specifying that: "I have never seen two groups in greater harmony and with such little intolerance [scil. Hanafis and Mālikìs]; I heard them tell extraordinary stories in this regard [on the authority] of their predecessors: they stated that in a given year, a magis-

${ }^{71}$ Ibn Hazm, Kitāb al-fisal fì l-milal wa-l-ahwā' wa-l-nihal, III, p. 142; Spanish trans. by Asín Palacios in Abehazán de Córdoba y su historia crítica de las ideas religiosas, V, p. 102; Kaddouri, "Refutations of Ibn Ḥazm by Mālikī authors from al-Andalus and North Africa," p. 541.

${ }^{72}$ In particular see Amari, Storia, II, pp. 16, 255-262, 542-562; Rizzitano, "Il contributo dei musulmani;" al-Dūrī, Șiqilliyya, pp. 179-183; Granara, "Islamic Education;" Chiarelli maintains his distance from such a historiographical position, without however providing a conclusive analysis, Chiarelli, A History, pp. 291-292.

${ }_{73}$ Al-Muqaddasī, Ahsan al-taqāsìm, in Amari, Biblioteca, I, p. 25; trans. I, p. 32; Amari, Storia, II, p. 359; al-Muqaddasī, The Best Divisions for Knowledge of the Regions, English trans. by Collins and Alta'i, p. 197.

${ }^{74}$ Madelung, "The Religious Policy," pp. 97-104.

75 On the situation in al-Andalus see Carmona "The introduction of Mālik's teaching in al-Andalus;" Fierro, "Proto-malikis, and reformed malikis in al-Andalus". 
trate (hākim) could be Hanafì, and in the following year, Mālikī”. ${ }^{76}$ It is not known to what degree this description by al-Muqaddasi can be applied to the Maghrib of the second half of the $10^{\text {th }}$ century, still strongly connected to Shī'î-Fătimid power and its propaganda; it is more plausible to think that the geographer instead based his views on an "antiquated" judgement, so to speak, dating from the first half of the $9^{\text {th }}$ century, during the time of Asad and Abu Muhriz.

This plurality in Sicily is clearly evidenced in various ways; for example, in the context of the second half of the $10^{\text {th }}$ century, the statement of Ibn Hawqal, who visited Palermo in 362/972-973, passes bitter judgement on the laxity of Muslims in the capital, where orthodox religious pratice was concerned, and also underlines a certain doctrinal ignorance or confusion with regard to the most noted theological positions, such as the Murji'a or the Mu'tazila. ${ }^{77}$

Where non-literary evidence is concerned, a certain level of antiMu'tazilī propaganda is clearly documented in the Qur'ān of Palermo (here the city is called Madinat Șiqilliyya), a manuscript dating from 372/982-983; on the folio 1v one reads: [1] Lā ilāh illā Allāh [2] Muhammad rasūl Allāh. [3] al-Qur'ān kalām Allāh [4] wa-laysa bimakhlūq, "There is no divinity other than Allāh, Muhammad is the messenger of Allāh, the Qur'ān is the word of Allāh, and it is not created;"78 this expression of faith, which is documented in various North African inscriptions (dating from the end of the $3^{\text {rd }} / 9^{\text {th }}$ century to the beginning of the $4^{\text {th }} / 11^{\text {th }}$ ), ought to be read and interpreted as a reaction to the diffusion of the Mu'tazila, spread by the Hanafis, which had started with the Aghlabids, and was gradually opposed by the Mālikî jurists, and/or by the élites of Fātimid power. ${ }^{79}$

${ }^{76}$ Al-Muqaddasī, Ahsan al-taqāsìm, ed. de Goeje, pp. 236-237; al-Muqaddasī, The Best Divisions for Knowledge of the Regions, English trans. by Collins and Alta'i, p. 195; see also the observations by Dachraoui, Le califat Fātimide, p. 402.

${ }_{77}$ Ibn Hawqal, Șurat al-ard, ed. Kramers, I, pp. 127-129; Ibn Hawqal, Configuration de la terre, French trans. by Kramers and Wiet, pp. 126-128.

${ }^{78}$ The Qur'ān of Palermo is held in Istanbul, Nurosmaniye Kütüphanesi 23 (two quires belong to the Khalili Collection in London, nos. 261 and 368 of the Déroche catalogue), measuring $17.6 \times 25 \mathrm{~cm}$, see Déroche, The Abbasid Tradition: Qur'ans of the $8^{\text {th }}$ to the $10^{\text {th }}$ centuries $A D$; Déroche, "Tradition et innovation dans la pratique de l'écriture au Maghreb pendant les IVe/ $\mathrm{X}^{\mathrm{e}}$ et $\mathrm{Ve} / \mathrm{XI}^{\mathrm{e}}$ siècles," pp. 237-238; Déroche, "Cercles et entrelacs: format et décor des Corans maghrébins médiévaux," pp. 600-604.

79 The Fātimid hypothesis is supported by Déroche, "Cercles et entrelacs," pp. 603604. 
This plurality was probably also significantly strengthened by the inclusion of groups from abroad; some Shì'iss, who had escaped from the massacre of 407/1016-17 in Ifriqiya, and survived the great famine of 395/1005, tried in vain to seek refuge in Sicily; clearly, the conflict between the Zirids and the Fâtimids did not directly involve the local Kalbid dynasty, who were ready to welcome the Shi' 'i groups that were fleeing the Mālikī Sunnī repression. ${ }^{80}$

In any case, beyond these particular doubts, it seems that Sicilian judges in the second half of the $10^{\text {th }}$ century had to face a chaotic and multifarious society, which seriously tested their capabilities, at least according to the statement of Ibn Hawqal:

Sicilians are the least intelligent men in the world, [indeed they are] the most stupid; they aspire less to worthy deeds and dedicate themselves avidly to cowardly ones. [Ibn Hawqal] adds: "More than one of them reported that 'Uthmān Ibn alKharrāz [or al-Khazzāz], a God-fearing man, managed their justice system (tawallà $\left.l-q \bar{a} d a^{\prime}\right)$, and as he had witnessed [the character of] that people, he did not want to accept any statements from any of them in small or large matters, and [he began] to enforce justice by [making] litigious parties come to agreements". Thus he practised until he was near death, when was asked who the person was who could replace him; then he replied: "In the whole country, there is no man who can be entrusted with this charge". When he died, administration of justice was charged to one man from the country called Abū Ibrāhīm Ishāa Ibn al-Mājalī [or alMașili].$^{81}$ [The writer here notes that Ibn Hawqal] repeated several acts of foolishness that were committed by him. ${ }^{82}$

Quite clearly, in Kalbid Sicily, the nomination of a judge was a question that by then no longer concerned North African leadership, and concerned instead the local sultān, or rather, the Kalbid emirs. The attempt by Ibn al-Kharrāz to bequeath his office ( $d \bar{\imath} w \bar{a} n)$, or rather administration of justice, to a foreigner from al-Qayrawān, a certain alGhaḍā'irî̀, was in vain. The loathed local canditate prevailed: Abū

${ }^{80}$ Amari, Storia, II, pp. 415-419; for a more general view see Chiarelli, $A$ History, p. 146; Bresc, "La Sicile et le Maghreb: relations politiques, migrations, transmissions culturelles".

${ }^{81}$ The question arises whether the controversial nisba should be amended in Ibn alMajjāni, verified in the island by the documents of the Geniza, see for example the Jewish merchant Mūsà b. Yahyà al-Majjānī (c. 1025), see Gil, "Sicily 827-1072," pp. 133, 136.

${ }^{82}$ The passage quoted here from Ibn Hawqal is the abbreviated version from Yàqūt, Mu jam al-buldān, in Amari, Biblioteca, I, p. 128; trans. I, p. 167; for the full version see Ibn Hawqal, Șūrat al-ard, ed. Kramers, I, pp. 124-125; Ibn Hawqal, Configuration de la terre, French trans. by Kramers and Wiet, pp. 123-124; for a detailed analysis see Gabrieli, "Ibn Hiawqal e gli Arabi di Sicila". 
Ibrāhīm Ishāq b. al-Mājalī, thanks to the support of the local élites ( $a h l$ al-balad), obtained the role of magistrate ( $h \bar{a} k \mathrm{kim})$ and preacher (khatīb) in the capital of the island. ${ }^{83}$

At the time of the events narrated anecdotally by Ibn Hawqal, the tie that bound Sicilian juridical culture to power in Ifrìiya was in some way broken; and it was at this very moment that Sicilian Mālikism took on a life of its own, that would give rise to the so-called school of Mazara and to the successive hijra, towards North Africa and the Arabo-Islamic world in general. ${ }^{84}$

\section{Appendix: Mālikī judges in Sicily from the main North African biographical dictionaries $\left(9^{\text {th }}-\right.$ first half of the $10^{\text {th }}$ century)}

1. 'Abd Allāh b. Sahl al-Qibryānī Abū Muhammad, born in 172/788-789 and died in 248/862 or 249/863, was one of the first pupils of Sahnūn, who later nominated him as $q \bar{a} d \bar{l}$ of Tulayțula, Gafsa and of the province of Nafzāwa; after the death of Sahnūn he became qā $d \bar{\imath}$ of Sicily. ${ }^{85}$

2. Muḥammad b. Sulaymān b. Sālim b. al-Qațạān Abū l-Rabī' al-qāḍ̄ known as Ibn al-Kaḥhāla (d. 289/901-902), mawlà of the Ghassān; pupil of Sahnnūn and his son, he followed the teaching of Muhammad b. Mālik b. Anas in Medina. Ibn Țālib appointed him judge of Bāja, while Ibn Sulaymān [known as Ibn Miskīn] was appointed supervisor of crimes (al-mazālim) in the city of al-Qayrawān within the limit of 100 dinārs; he was imprisoned by Ibn 'Abdūn ${ }^{86}$ was later nominated as $q \bar{a} d \bar{\imath}$ of Sicily "where he went and contributed enormously to the diffusion of culture in that geographical area. His departure for Sicily dates from 281/894-895. With regard to this, al-Shīrāzī

${ }^{83}$ Ibn Hawqal, Șūrat al-ard, ed. Kramers, I, pp. 124-125; Ibn Hawqal, Configuration de la terre, French trans. by Kramers and Wiet, pp. 123-124.

${ }^{84}$ On the school of Mazara and his "namesakes" see Asín Palacios, "Un faqìh siciliano contradictor de al-Ghazālì (Abū 'Abd Allāh de Mazara);" Idris, "L'école mālikite;" Rizzitano, "Il contributo dei musulmani," pp. 485-486; Borruso, al-Imàm al-Màzari; Garden, "al-Mazarī al-Dhakī: al-Ghazālì’s Maghribī Adversary in Nishapur".

${ }^{85}$ Abū 1-'Arab, Classes des savants, pp. 216-217, 253; al-Qāọī 'Iyāọ, Tartīb al-madārik, II, pp. 94-95; De Luca, Giudici e giuristi, pp. 52-53; Granara, "Islamic Education," pp. 163-164.

86 "Ibn 'Abdūn sent Sulaymān b. Sālim to prison, the qā dị of Bāja and its surrounding; later, he became judicial official (hăkim) in al-Qayrawān at the time of Ibn Miskin, and then, was charged with administering justice in Sicily, where he died," Abū 1-'Arab, Kitāb al-mihan, p. 465. 
adds:87 'Thanks to him, Mālikī madhhab has been disseminated in Sicily'. He carried out the role of judge in the island until his death in 289/901-902. He did not leave any inheritance." 88

3. Di‘āma b. Muhammad (d. 297/910) was also a pupil of Sahnūn who occupied the post of head judge in Sicily during the Aghlabid period; the Kitāb al-mihan relates that he was removed and imprisoned by Ibrāhìm before his departure for the jihād in 289/902. ${ }^{89}$

4. Abū 'Amr Maymūn b. 'Amr al-Ma'lūf(d. 316/928-929), a pupil of Sahnūn, the supervisor of crimes (al-mazālim) in al-Qayrawān before being invited to be $q \bar{a} d \bar{\imath}$ in Sicily; al-Mālikī relates that: "When he was promoted to this office, passing through Sūsa [to go to take up his role] he said to the people: "O people of Sūsa, this is the dress, my fur, this is the bag with my books and this is the black woman who serves me, who has with her a coat and a dress. With these things I come to you: bear this in mind [and then you will see] what I will bring back". Abū Rabī' says: "I know from the Sicilian Sa'īd b. 'Uthmān that when Abu 'Amr arrived in [the capital of] Sicily, we said to him: this is the house of the $q \bar{a} d \bar{l}$; alight here". To which he replied: "It is too big, how could I stay here?". He stayed, then, in a modest, small house, in which the black servant was dedicated to the task of spinning wool; she sold the wool and spent what she earned on her master. When someone knocked on the door, she went out and said: "Wait for the qā $d \bar{\imath}$ to come". Things carried on in this way, until he fell ill and stayed for three days without leaving the house; then people went there to knock on the door and the black woman appeared saying: "Come in, gentleman, to visit the qā $\bar{l} \bar{l}$, who is ill". [Sa'îd continues]: "We entered and found that he was resting his head on two pillows stuffed with straw, and lying on a papyrus mat. When he saw us, he began to cry and said: "I swear to God, I have made every effort [to uphold my office] as far as I could". He left Sicily, still unwell, saying to the people: "May God give you a better $q \bar{a} d \bar{\imath}$ than me". To which they replied: "May God give you health!". Arriving in Sūsa, he said to the people [who welcomed him]: "O people of Sūsa, as we came here, so we go back. This is my dress, this is my

${ }^{87}$ Abū Ishạa b. 'Alī b. Yūsuf al-Fìrūzābādī al-Shīrāzī (393/1003-476/1083) Shāfíī jurist, and author, amongst other works, of Tabaqāt al-fuqahă', see De Luca, Giudici e giuristi, p. 58, no. 44.

${ }^{88}$ Abū 1-'Arab, Classes des savants, p. 234; al-Qāḍī 'Iyāọ, Tartīb al-madārik, II, pp. 233-235; De Luca, Giudici e giuristi, pp. 56-58; Granara, "Islamic Education," p. 164.

${ }^{89}$ Abū 1-'Arab, Kitāb al-mihan, p. 464; Ibn 'Idhārī, al-Bayān al-mughrib, in Amari, Biblioteca, I, p. 418; trans. II, p. 470; Amari, Storia, II, p. 259; Granara, "Islamic Education," p. 164. 
coat and my bag of books, and this is the black woman who takes care of my house" .90

5. Abū 1-Qāsim Muhammad b. Muhammad b. Khālid al-Qaysī, client (mawlà) of the Banū Ma'bad, "the servant" (al- 'abìd), known as al-Ṭarāzì (d. 317/929), ${ }^{91}$ pupil of Saḥnūn, succeeded 'Īsà b. Miskīn and Himās b. Marwān in al-Qayrawān as the supervisor of crimes (al-mazālim), as well as being in control of its markets (al-hisba). The Qāḍī 'Iyāḍ relates an anecdote: "Ibn alJazzār remembers that, when he was given the role, he scoffed, saying he was shy, compliant and inexperienced. The emir Ibn al-Aghlab then said: 'Your timidity and compliance will disappear when you give orders and interdictions, and where your lack of experience is concerned... consult the jurists!" ". ${ }^{92}$ Nominated head judge of Sicily by the Aghlabid prince Ziyâdat Allāh III (903-909) "he showed himself to be a severe and intransigent decision-maker, receiving much praise for his conduct;" 93 then al-Ṭarāzì was removed from the judiciary of Sicily and imprisoned, together with Abu 1-‘Abbās b. Ishạāq b. Ibrāhīm known as Ibn Bațīqa, faqīh and $q \bar{a} d \bar{\imath}$ of Tripoli. ${ }^{94}$ His persecution is due to al-Marwazì ${ }^{95}$ and as the Qāḍ̄ 'Iyāọ writes, he is included in the repression "of some exponents of the circle of the Medinans [Mālikīs] like Ibn Salmūn al-Qatțān, the muhtasib al-Hallāb and some murābitūn of Tunis. But it was because of them that al-Marwazì later died. Indeed, when the Shī'ī imām 'Ubayd Allāh arrived in al-Qayrawān from Sijilmāsa, he confirmed him as judge and left those men in prison. But they began to

90 Al-Mālikī, Riyāẹ al-nufūs, in Amari, Biblioteca, I, pp. 222-223; trans. I, pp. 255256; Granara, "Islamic Education," p. 164.

${ }^{91}$ The name Calatrasi (< Ar. Qal 'at [al-]Ṭarāzì, "the Fortress of [al-]Ṭarāzī”), the place that is now Monte Maranfusa in the province of Palermo, could derive from this particular nisba, if not from the judge himself who perhaps held (allodially?) this land; the etymology of the place name is generally explained as Qal 'at al-tirāz ("the Fortress of the Workshop[-s]") or more frequently as Qal 'at al-țirāzi ("the Fortress of the Embroiderer"), as suggested by Caracausi, Dizionario onomastico della Sicilia, I, p. 240; on the archeological site see Brunazzi, Il castello di Calatrasi. Le strutture e l'impianto: prime considerazioni, in Archeologia e territorio.

92 Al-Qāḍi 'Iyāọ, Biographies aghlabides extraites des Madārik du Cadi 'Iyād, pp. 377-379; De Luca, Giudici e giuristi, pp. 58-61.

93 Abū 1-'Arab, Classes des savants, pp. 211-212; De Luca, Giudici e giuristi, p. 59; Granara, "Islamic Education," p. 164.

94 Abū l-'Arab, Kitāb al-mihan, p. 466, see also al-Mālikī, Riyā ḍ al-nufūs, in Amari, Biblioteca, I, pp. 219-220; trans. I, p. 253.

95 Muhammad b. 'Umar b. Yahyà b. 'Abd al-A 'là al-Marwazī (al-Marwadīi or al-Mar-

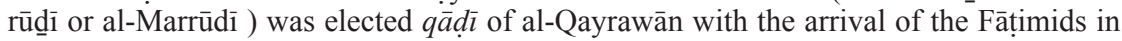
909, see Monès, “Le Malekisme,” pp. 209-210; De Luca, Giudici e giuristi, p. 61 no. 51. 
accuse al-Marwazi of embezzlement and other crimes, so that he was removed from office, tortured and killed, may God take him! With regard to al-Ṭarāzì, he died in 317/929-930". ${ }^{96}$

6. Muhammad b. Ibrāhīm b. Abī Sabīh, an eminent jurist whose family was originally from the Arabian Peninsula; an expert in medicine, he studied law with Sahnūn and was nominated judge of Sicily by Himās, "and it is said that he, going there, even brought with salt him from Ifriqiya, due to his excessive zeal". He was removed from his position for having neglected his duties and was imprisoned by Ziyādat Allāh III; he remained in prison even at the time of the Fātimids and died at Sūsa in 334/945-46". ${ }^{97}$

96 Al-Qāḍī 'Iyāḍ, Biographies aghlabides, pp. 377-379; De Luca, Giudici e giuristi, pp. 60-61.

${ }^{97}$ Al-Qāḍị 'Iyāḍ, Tartīb al-madārik, II, p. 357; De Luca, Giudici e giuristi, p. 66; Granara, "Islamic Education," p. 164. 


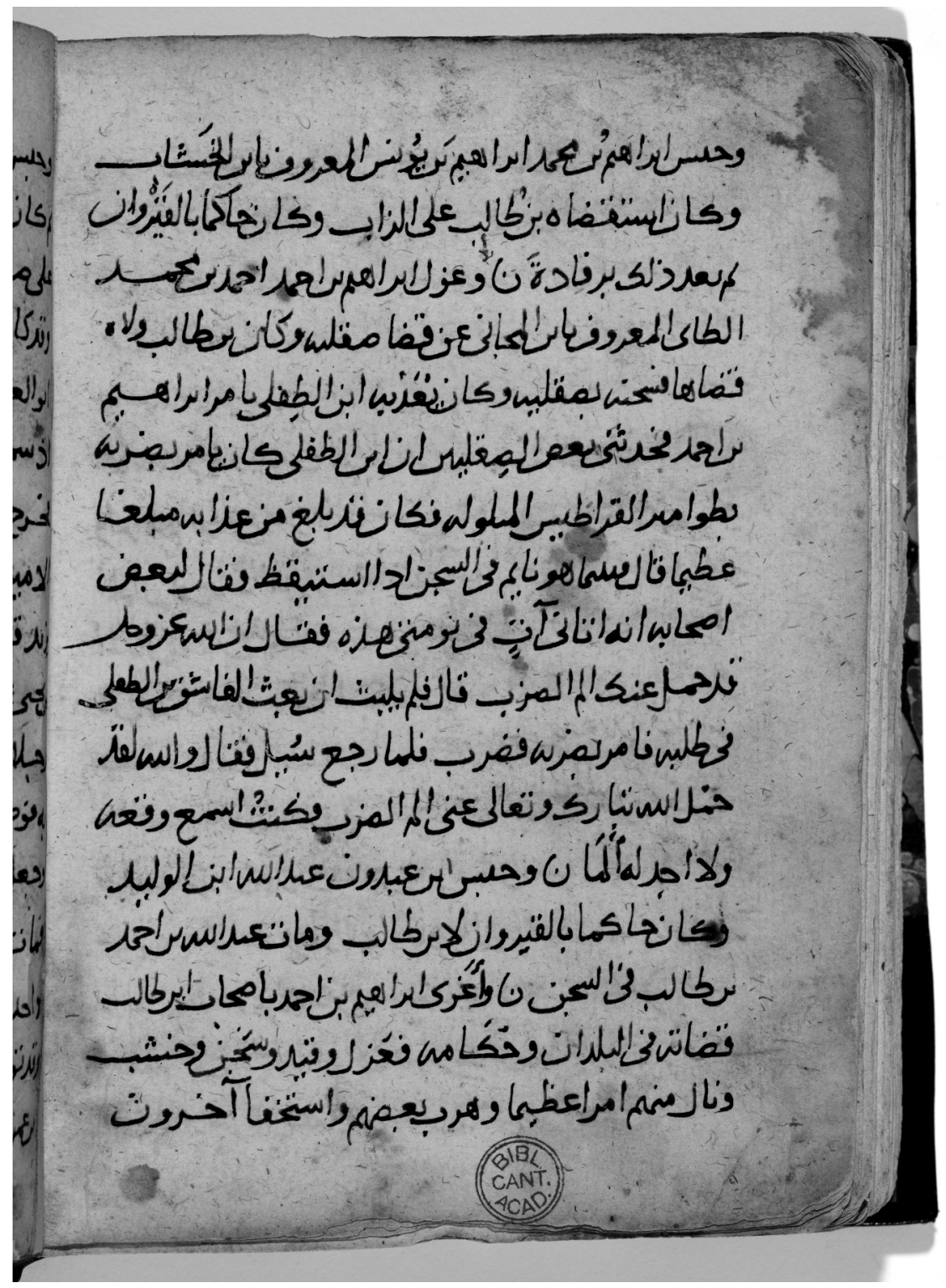

Figure 1: Abū l-`Arab Muḥammad al-Tamīmī, Kitāb al-miḥān, Ms. Cambridge, University Library, Qq. 235, f. 178 v 


\section{Sources and bibliography}

\section{Sources}

Abū 1-'Arab Muhammad b. Aḥmad b. Tamīm, Kitāb al-mihan, Cambridge, University Library, Qq. 235; Arabic ed.: Kitāb al-mihan, Yahyà Wahīb al-Jubūrī (ed.), Beirut, Dār al-Gharb al-islāmī, 1983.

Abū l-'Arab Muḥammad b. Aḥmad b. Tamìm, Țabaqāt 'ulamā'Ifrìqiya, in Mohammed Ben Cheneb, "Additions à la 'Biblioteca arabo-sicula', tirées des recueils biographiques d'Abou 1-'Arab et d'el Khochany; suivies d'une notice sur un manuscrit des 'Madārik' du Qāḍ̄i 'Iyāḍ,'” in Scritti per il centenario della nascita di Michele Amari, I-II, Palermo, Stabilimento tipografico Virzì, 1910, I, pp. 241-276; French translation: Abū 1-'Arab Muhammad b. Ahmad b. Tamìm/Muhammad b. al-Hārith b. Asad al-Khushanī, Classes des savantes de l'Ifriquya, Mohammed Ben Cheneb (trans.), Alger, Pubblications de la Faculté des Lettres d'Alger, 1920.

Amari, Michele (ed.), Biblioteca arabo-sicula, Arabic text and translation, $2^{\text {nd }}$ ed. revised by Umberto Rizzitano, Arabic text I-II, Palermo, Accademia Nazionale di Scienze Lettere e Arti, 1988; translation I-III, Palermo, Accademia Nazionale di Scienze Lettere e Arti, 1997-1998.

Al-Dāwudī, Abū Ja'far Aḥmad b. Naṣr, Kitāb al-amwāl, Abu'l Muhsin Muhammad Sherfuddin (ed.), Islamabad, Islamic Research Institute, 1995.

Epistola Theodosii monachi de excidio Syracusarum, in [Gaetani Ottavio, (ed.)], Vitae sanctorum siculorum ex antiquis graecis latinisque monumentis, et ut plurimum ex manuscriptis codicibus nondum editis collectae, aut scriptae, digestae iuxta seriem annorum christianae epochae, et animadversionibus illustratae a R. P. Octavio Caietano, I-II, Palermo, Apud Cirillos, 1657, II, pp. 272-277.

Ibn Ḥawqal, Șūrat al-ard, Joel H. Kramers (ed.), I-II, Leiden, Brill, 1938-39, $2^{\text {nd }}$ ed.; French trans.: Configuration de la terre, Joel H. Kramers and Gaston Wiet (trans.), I-II, Paris, Maisonneuve et Larose, 1964.

Ibn al-Haytham, Kitāb al-munāzarāt. The Advent of the Fàtimids. A Contempo-

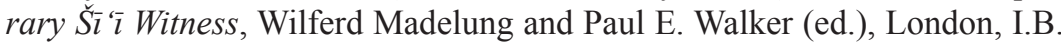
Tauris, 2001.

Ibn Ḥazm, 'Alī b. Aḥmad, Kitāb al-fiṣal fì l-milal wa-l-ahwā' wa-l-niḥal, Aḥmad Shams al-Dīn (ed.), I-III, Beirut, Dār al-kutub al-'ilmiyya, 1999/1420; Spanish trans.: Miguel Asín Palacios, Abenhazám de Córdoba y su historia crítica de las ideas religiosas, I-V, Madrid, Revista de archivos, 1927-1932.

Ibn 'Idhārī, al-Bayān al-mughrib, Georges S. Colin and Évariste Lévi-Provençal (ed.), I-IV, Leyde, Brill, 1948-1951, reprinted Beirut, Dār al-thaqāfa, 1967.

Ibn Khaldūn, Kitāb al-'ibar. Al-Muqaddima, Beirut, Dār al-kitāb al-lubnānī, 195659 (2nd ed. Beirut 1961); French trans.: Les prolégomènes d'Ibn Khaldoun, 
William MacGuckin de Slane (trans.), I-III, Paris, Imprimerie impériale, 18631868, Notices et extraits des manuscrits de la Bibliothèque impériale, 19-20. Kitāb al- 'uyūn wa-l-hadā' 'iq fi akhbār al-haqā'iq, 'Umar al-Sa'īdì (ed.), I-II, Damascus, Institut Français du Proche-Orient, 1972-1973.

Al-Muqaddasī, Ahsan al-taqāsìm fì ma 'rifat al-aqālìm, Michael Jan de Goeje (ed.), Leiden, Brill, 1906; English trans.: The Best Divisions for Knowledge of the Regions. Ahsan al-taqāsìm fì ma 'rifat al-aqālìm, Basil Collins and Mohammad Hamid Alta'i (trans.), Reading (UK), Garnet Publishing, 2001.

Al-Qāḍī 'Iyāḍ, Biographies aghlabides extraites des Madārik du Cadi 'Iyād, Mohamed Talbi (ed.), Tunis, Université de Tunis, 1968.

Al-Qāḍī 'Iyāọ b. Mūsà, Tartīb al-madārik wa-taqrīb al-masālik fì ma 'rifat a 'lām madhhab Mālik, Aḥmad Bākir Mạ̣mūd (ed.), Beirut, Dār maktabat al-ḥayāt, 1967-68/1387-1388.

\section{Bibliography}

Amara, Allaoua, "L'Islamisation du Maghreb central (VII'-XI" siècle)," in Dominique Valérian (ed.), Islamisation et arabisation de l'Occident musulman médiéval (VII ${ }^{e}$-XII ${ }^{e}$ siècle), Paris, Publications de la Sorbonne, 2011, pp. 103-128, Bibliothèque Historique des Pays d'Islam, 2.

Amari, Michele, Storia dei Musulmani di Sicilia, Carlo Alfonso Nallino (ed.), IIII, Catania, R. Prampolini, 1933-1939, $2^{\text {nd }}$ ed.

Anastasi, Rosario, “L'epistola di Teodosio monaco," Archivio Storico Siracusano, n.s. 5 (1978-1979), pp. 169-182.

Asín Palacios, Miguel, "Un faq̄̄h siciliano contradictor de al-Ghazālī (Abū 'Abd Allāh de Mazara)," in Scritti per il centenario della nascita di Michele Amari, I-II, Palermo, Stabilimento tipografico Virzì, 1910, II, pp. 216-244.

Ben Sasson, Menahem, The Jews of Sicily (825-1068), Jerusalem, Ben-Zvi Institute, 1991.

Bernards, Monique, "Talab al- 'ilm amongst the linguists of Arabic during the "Abbasid period," in James E. Montgomery (ed.), 'Abbasid studies: occasional papers of the School of 'Abbasid Studies, Cambridge, 6-10 July 2002, Leuven-Paris-Dudley, Peeters Publishers, 2004, pp. 33-46.

Biberstein Kazimirski, Albert de, Dictionnaire arabe-français, I-II, Paris, Maisonneuve, 1860.

Borruso, Andrea, al-Imàm al-Màzari. Un mazarese del medioevo arabo-islamico, Mazara del Vallo, Liceo ginnasio Gian Giacomo Adria, 1984, Quaderni del Corso al-Imām al-Māzarī, 6.

Bresc, Henri, "La Sicile et le Maghreb: relations politiques, migrations, transmissions culturelles," in Philippe Sénac (ed.), Histoire et archéologie de l'Occi- 
dent musulman (VII ${ }^{e} X V^{e}$ siècles). Al-Andalus, Maghreb, Sicile, Toulouse, CNRS-Université de Toulouse-Le Mirail, 2012, pp. 201-219.

Brockopp, Jonathan E., “Asad b. al-Furāt," in Gudrun Krämer et al. (ed.), The Encyclopaedia of Islam Three, Leiden-Boston, Brill, 2008, I, pp. 169-71.

Brunazzi, Valeria, Il castello di Calatrasi. Le strutture e l'impianto: prime considerazioni, in Archeologia e territorio, Palermo, G.B. Palumbo, 1997, pp. 319-410. Caracausi, Girolamo, Dizionario onomastico della Sicilia, I-II, Palermo, Centro di studi filologici e linguistici siciliani, 1994.

Carmona, Alfonso, "The introduction of Mālik's teaching in al-Andalus," in Peri Bearman, Rudolph Peters and Frank E. Vogel (ed.), The Islamic School of Law. Evolution, Devolution and Progress, Cambridge, Harvard University Press, 2005, pp. 41-56.

Chiarelli, Leonard C., A History of Muslim Sicily, Malta, Midsea Books, 2011.

Chiarelli, Leonard C., "The Ibāḍi Presence in Muslim Sicily," Bulletin of the Royal Institute for Inter-Faith Studies, 7, 1 (2005), pp. 69-89.

Chiarelli, Leonard C., "The Ibādīyah in Muslim Siciliy," Al- 'Ușūr al-Wusțà. The Bulletin of Middle East Medievalists, 16, 1 (2004), pp. 11-17.

Cook, David, Martyrdom in Islam, Cambridge, Cambridge University Press, 2007.

Cusa, Salvatore, I diplomi greci e arabi di Sicilia, I, 1-2, Palermo, Stab. tip. Lao, 1868-1882.

Dachraoui, Farhat, Le califat fạtimide au Maghreb (296-365 H./909-975 J. Ch.). Histoire politique et institutions, Tunis, STD, 1981.

De Luca, Maria Amalia, Giudici e giuristi nella Sicilia musulmana. Notizie e biografie estratte dal Tartīb al-madārik, Palermo, Istituto per la Diffusione della Cultura Araba Siciliana e Mediterranea, 1989.

De Simone, Adalgisa, "In margine alla fiscalità islamica in Sicilia," in Fabiola Ardizzone and Annliese Nef (ed.), Le processus d'islamisation en Sicile et en Méditerranée centrale (Palermo, 8-10 novembre 2012), Roma-Bari, École française de Rome-Edipuglia, in press, pp. 59-68.

Déroche, François, The Abbasid Tradition: Qur'ans of the $8^{\text {th }}$ to the $10^{\text {th }}$ centuries $A D$, New York, The Nour Foundation in association with Azmuth Editions and Oxford University Press, 1992, Nasser D. Khalili Collection of Islamic Art, 1.

Déroche, François, "Cercles et entrelacs: format et décor des Corans maghrébins médiévaux," Comptes-rendus des séances de l'Académie des Inscriptions et Belles-Lettres, 145, 1 (2001), pp. 593-620.

Déroche, François, "Tradition et innovation dans la pratique de l'écriture au Maghreb pendant les IV $/ \mathrm{X}^{\mathrm{e}}$ et $\mathrm{V} / \mathrm{XI}^{\mathrm{e}}$ siècles," in Serge Lancel (ed.), Numismatique, langues, écritures et arts du livre, spécificité des arts figurés. Actes $d u \mathrm{VII}^{\mathrm{e}}$ colloque international sur l'histoire et l'archéologie de l'Afrique du Nord, Paris, Éditions du Comité des travaux historiques et scientifiques, 1999, pp. 233-246. 
Di Branco, Marco, "Due notizie concernenti l'Italia meridionale dal Kitāb al'uyūn wa'l-hadā'iq fi ahbār al-haqā'iq (Libro delle fonti e dei giardini riguardo la storia dei fatti veridici)," Archivio storico per la Calabria e la Lucania, LXXVII (2011), pp. 1-9.

Dozy, Reinhart, Supplément aux dictionnaire arabes, I-II, Leyde, Brill, 1881.

Al-Dūrī, Tāqī al-Dīn, Șiqilliyya. 'Alāqātu-hā bi-duwal al-baḥr al-mutawassiṭ alislāmiyya min al-fath al- 'arabì hattà l-ghazw al-nūrmandī, Baghdad, Manshūrāt wizārat al-thaqāfa wa-l-a'lām - al-Jumhūriyya al-'irāqiyya, 1980.

El Hour, Rachid and Mayor, Rafael (ed.), Cadies y cadiazgo en al-Andalus y el Magreb medieval, Madrid, CSIC, 2012, Estudios Onomástico-Biográficos de al-Andalus, XVIII.

Fagnan, Edmond, "Les tabakāt malekites," in Eduardo Saavedra (ed.), Homenaje a D. Francisco Codera en su jubilación del profesorado. Estudios de erudición oriental, Zaragoza, Mariano Escar. Tipógrafo, 1904, pp. 99-113.

Fenina, Abdelhamid, "La ville de Mağğāna sous Ziyādat Allāh I: un atelier monétaire peu connu et une principauté éphémère à l'époque ag̉labide," Arabica, 55 (2008), pp. 204-226.

Fierro, Maribel, "Proto-malikis, and reformed malikis in al-Andalus," in Peri Bearman, Rudolph Peters and Frank E. Vogel (ed.), The Islamic School of Law. Evolution, Devolution and Progress, Cambridge, Harvard University Press, 2005, pp. 57-76.

Gabrieli, Francesco, "Ibn Hawqal e gli Arabi di Sicila," Rivista degli Studi Orientali, XXXVI (1961), pp. 245-53; reprinted in L'Islam nella storia, Bari 1966, pp. 57-67.

Gacek, Adam, The Arabic Manuscript Tradition. A Glossary of Technical Terms \& Bibliography, Leiden, Brill, 2001, Handbook of Oriental Studies, 58.

Garden, Kenneth, "al-Māzarī al-Dhakī: al-Ghazālī’s Maghribī Adversary in Nishapur,” Journal of Islamic Studies, 21, 1 (2010), pp. 89-107.

Gil, Moshe, "Sicily 827-1072, in light of the Geniza documents and parallel sources," in Gli ebrei di Sicilia sino all'espulsione del 1492. Atti del V convegno internazionale Italia Judaica (Palermo 1992), Roma, Ministero per i Beni Culturali e Ambientali. Ufficio Centrale per i beni archivistici, 1995, pp. 96-171, Pubblicazioni degli Archivi di Stato. Saggi, 32.

Granara, William, "Islamic Education and the Transmission of Knowledge in Muslim Sicily," in Joseph E. Lowry, Devin J. Stewart and Shawkat M. Toorawa (ed.), Law and Education in Medieval Islam: Studies in Honor of George Makdisi, London, EJW Gibb Memorial Trust, 2004, pp. $150-173$.

Hentati, Nejmeddine, "La prison en Occident musulman medieval," Arabica, 54, 2 (2007), pp. 149-188.

Idris, Hady Roger, “L'aube du malikisme ifrīqiyen,” Studia Islamica, 33 (1971), pp. 19-40. 
Idris, Hady Roger, "L'école mālikite de Mahdia. L'imām al-Māzarī (m. 536 H/1141)," in Études d'orientalisme dédiés à la mémoire de Lévi-Provençal, I-II, Paris, G.-P. Maisonneuve et Larose, 1962, I, pp. 153-163.

Idris, Hady Roger, "Réflexions sur le malekisme sous les umayyades d'Espagne," in Atti del terzo Congresso di studi arabi e islamici. Ravello, 1-6 settembre 1966, Napoli, Istituto Universitario Orientale, 1967, pp. 396-414.

Kaddouri, Samir, "Refutations of Ibn Ḥazm by Mālikī authors from al-Andalus and North Africa," in Camilla Adang, Maribel Fierro and Sabine Schmidtke (ed.), Ibn Hazm of Cordoba. The Life and Works of a Controversial Thinker, Leiden-Boston, Brill, 2013, pp. 539-599.

Kister, Meir J., "The Kitab al-Mihan, a Book on Muslim Martyrology," Journal of Semitic Studies, 20 (1975), pp. 210-218.

Lavagnini, Bruno, "Siracusa occupata dagli Arabi e l'epistola di Teodosio monaco,” Byzantion, 29-30 (1959-60), pp. 267-277.

Longo, Ruggero, La fabbrica medievale, in Maria Andaloro (ed.), Il Palazzo Reale di Palermo, Modena, Franco Cosimo Panini, 2010, pp. 51-97.

Lory, Pierre, Le rêve et ses interprétations en Islam, Paris, Albin Michel, 2003.

Madelung, Wilferd, "The Religious Policy of the Fātimids towards their Sunni Subjects in the Maghrib," in Marianne Barrucand (ed.), L'Égypte Fātimide, son art et son histoire, Paris, Presses de l'Université de Paris-Sorbonne, 1999, pp. 97-104.

Mandalà, Giuseppe, "Una nueva fuente para la historia de la Sicilia islámica. La revuelta de Ahmad Ibn Qarhab (300-304/913-916) en un pasaje de alMuqtabis V de Ibn Hayyān," Al-Qanțara, 33, 2 (2012), pp. 343-374.

Mansouri, Mohamed Tahar, "Les 'ulamā' en rupture avec le pouvoir en Ifrīqiya d'après le Kitāb al-mihan," Mélanges de l'École Française de Rome. Moyen Âge, 115, 1 (2003), pp. 565-580.

Marín, Manuela, "Shurța," in C.E. Bosworth et al. (ed.), The Encyclopaedia of Islam. New Edition, IX, Leiden, Brill, 1997, pp. 510-512.

Monès, Hussain, "Le malékisme et l'échec des fătimides en Ifrīqiya," in Études d'Orientalisme dédiées à la mémoire de Lévi-Provençal, I-II, Paris, G.-P. Maisonneuve et Larose, 1962, I, pp. 197-220.

Nef, Annliese, "Comment les Aghlabides ont décidé de conquérir la Sicile...," Annales Islamologiques, 45 (2011), pp. 191-210.

Nef, Annliese, "La désignation des groupes ethniques de la Sicile islamique dans les chroniques en langue arabe. Source d'information ou topos?," Annales Islamologiques, 42 (2008), pp. 57-72.

Nef, Annliese, "La fiscalité en Sicile sous la domination islamique," in Annliese Nef and Vivien Prigent (ed.), La Sicile de Byzance à l'Islam, Paris, De Boccard, 2010, pp. 131-156.

Nef, Annliese, "Instruments de légitimation politique et légitimité religieuse dans l'Ifrìqiya de la fin du IX ${ }^{\mathrm{e}}$ siècle. L'exemple d'Ibrāhīm II (875-902),' in 
Annliese Nef and Élise Voguet (ed.), La légitimation du pouvoir au Maghreb médiéval. De l'orientalisation à l'émancipation politique, Madrid, Casa de Velázquez, 2011, pp. 75-92.

Nef, Annliese, "Violence and the prince: the case of the Aghlabid amīr Ibrāhīm II (261-289/875-902)," in Christian Lange and Maribel Fierro (ed.), Public Violence in Islamic Societies. Power, Discipline and the Construction of the Public Sphere, $7^{\text {th }}-19^{\text {th }}$ Centuries CE, Edinburgh, Edinburgh University Press, 2009, pp. 217-237.

Penelas, Mayte, "Introducción a la doctrina mālikí sobre el martirio," in Maribel Fierro (ed.), De muerte violenta. Política, religión y violencia en al-Andalus, Madrid, CSIC, 2004, pp. 451-475, Estudios Onomástico-Biográficos de AlAndalus, XIV.

Puente, Cristina de la, "En las cárceles del poder: prisión en al-Andalus bajo los omeyas (ss. II/VIII-IV/IX)," in Maribel Fierro (ed.), De muerte violenta. Política, religión y violencia en al-Andalus, Madrid, CSIC, 2004, pp. 103-133, Estudios Onomástico-Biográficos de al-Andalus, XIV.

Purpura, Gianfranco, "Graffiti di navi normanne nei sotterranei del Palazzo Reale di Palermo," Sicilia Archeologica, XIII, 44 (1981), pp. 43-54.

Rizzitano, Umberto, “Asad b. al-Furāt faqīh e qā dị d'Ifrīqiya," Rivista degli Studi Orientali, 36 (1961), pp. 225-243.

Rizzitano, Umberto, "Il contributo dei musulmani di Sicilia alla diffusione del fiqh mālikita," Studi e materiali di storia delle religioni, 38, 1-2 (1967), pp. 473-487.

Rognoni, Cristina, "Au pied de la lettre? Réflexions à propos du témoignage de Théodose moine et grammaticos sur la prise de Syracuse en 878," in Annliese Nef and Vivien Prigent (ed.), La Sicile de Byzance à l'Islam, Paris, De Boccard, 2010, pp. 205-228.

Rosenthal, Franz, “Abū 1-'Arab Muhammad b. Tamīm b. Tammām al-Tamīmī," in The Encyclopaedia of Islam. New Edition, Hamilton A. R. Gibb et al. (ed.), I, Leiden, Brill, 1960, p. 106.

Schneider, Irene, "Imprisonement in Pre-Classical and Classical Islamic Law," Islamic Law and Society, 2 (1995), pp. 157-173.

Schreiner, Peter (ed.), Die Byzantinischen Kleinchroniken. 1, Einleitung und Text, Wien, VÖAW, 1975-1979, Corpus fontium historiae Byzantinae. Series Vindobonensis, 12,1 .

Simonsohn, Shlomo, The Jews in Sicily, I-XVIII, Leiden-New York-Köln, Brill, 1997-2010.

Talbi, Mohamed, L'émirat aghlabide 184-296/808-909. Histoire politique, Paris, Librairie d'Amérique et d'Orient Adrien Maisonneuve, 1966.

Talbi, Mohamed, "Theological Polemics at Qayrawan during the $3^{\text {rd }}-9^{\text {th }}$ century," Rocznik Orientalistyczny, 43 (1984), pp. 151-160.

Tillier, Mathieu, Les cadis d'Iraq et l'État abbasside (132/750-334/945), Damas, Institut Français du Proche-Orient, 2009. 
Tillier, Mathieu, "Les prisonniers dans la société musulmane (II $/ \mathrm{VIII}$-IVe/X $\mathrm{X}^{\mathrm{e}}$ siècle)," in Elisabeth Malamut (ed.), Dynamiques sociales au Moyen Âge en Occident et en Orient, Aix-en-Provence, Publications de l'Université de Provence, 2010, pp. 191-212.

Tillier, Mathieu, "Prisons et autorités urbaines sous les Abbasides," Arabica, 55 (2008), pp. 387-408.

Tillier, Mathieu, "Vivre en prison à l'époque abbaside," Journal of the Economic ad Social History of the Orient, 52 (2009), pp. 635-659.

Tsafrir, Nurit, The History on Islamic School of Law. The Early Spread of Hanafism, Cambridge Mass., Harvard University Press, 2004.

Walker, Paul E., "Introduction," in Ibn al-Haytham, Kitāb al-munāzarāt. The Advent of the Fàtimids. A Contemporary $\check{S}_{\bar{l}}$ ' $\mathrm{l}$ Witness, Wilferd Madelung and Paul E. Walker (ed.), London, I.B. Tauris, 2001, pp. 1-59.

Zuretti, Carlo Oreste, "Italoellenika [1]. La espugnazione di Siracusa nell' 880. Testo greco della lettera del monaco Teodosio", in Scritti per il centenario della nascita di Michele Amari, I-II, Palermo, Stabilimento tipografico Virzì, 1910, I, pp. 165-173.

Recibido: 29/07/2013

Aceptado: 28/02/2014 